\title{
The Atlantic Salmon (Salmo salar) Vertebra and Cellular Pathways to Vertebral Deformities
}

\author{
Elisabeth Ytteborg1, Jacob Torgersen ${ }^{1}$, \\ Grete Baeverfjord ${ }^{1}$ and Harald Takle ${ }^{1,2}$ \\ ${ }^{1}$ Nofima AS, Norwegian Institute of Food, \\ Fisheries and Aquaculture Research \\ ${ }^{2}$ AVS Chile S.A. \\ ${ }^{1}$ Norway \\ ${ }^{2}$ Chile
}

\section{Introduction}

Stagnating fish stocks and a growing population demanding for aquatic food products have been the major driving forces behind the rapid increase in aquaculture production. Federation of European Aquaculture Producers (FEAP) estimates that 650000 tons of fish are farmed in the EU annually (compared to 60000 tons in 1970). Within Europe as a whole, the total production is more than 1.6 million tons (FEAP, 2009). Norway is a major contributor to Europe's aquaculture sector with over 860000 tons of Atlantic salmon (Salmo salar) and trout produced each year, a production that has been more than doubled the last ten years (Directorates of fisheries, Norway 2009). Forecasts predict that production will need to increase for decades to come if demands are to be met (Brugere \& Ridler 2004). To keep up with the growing demand, the aquaculture industry is constantly searching for new strategies to improve the rearing conditions and reduce production time and cost. However, as a relatively new industry, and as a consequence of intensified production regimes, the aquaculture sector faces growth constraints.

Farmed salmon is bred for rapid growth, and the industry aim at obtaining the optimal growth rate by optimizing both diets and environmental factors accordingly. However, intensive rearing conditions are linked to increased occurrence of production related diseases and malformations. Elevated temperature during the fresh water period was commonly used in the 90 ies to speed up developmental rate. An increasing number of fish developing manufacturing defects, such as skeletal abnormalities (figure 1), heart failure and jaw deformities was observed. Recommendations limiting temperatures to safe levels, $\leq 8^{\circ} \mathrm{C}$ during egg rearing and $\leq 12^{\circ} \mathrm{C}$ after fist feeding, led to substantial reductions in skeletal malformations (Baeverfjord et al., 1999). However, in the last few years, the start feeding temperature has been increased again, due to the stakeholders demand for reduced production time. Further, the growing need of replacing fish meal in commercial fish feeds have come into focus and deformities related to feed ingredient replacements, malnutrition and mineral deficiency are investigated. 

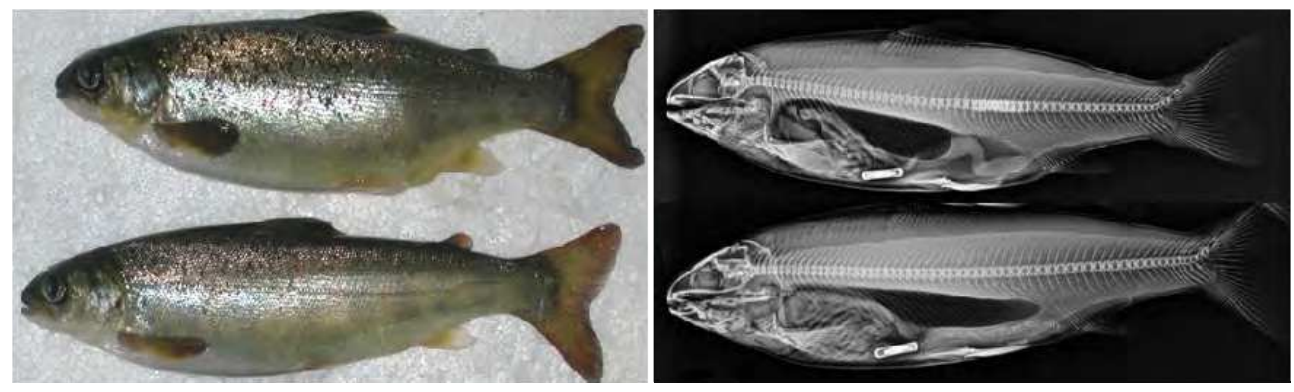

Fig. 1. Deformed (top) and non-deformed Atlantic salmon and corresponding radiographic pictures. Photo: Grete Baeverford, Nofima.

In the present situation, fast growth in combination with unpredictable and potentially low bioavailability of nutrients is considered the main challenge for adequate skeletal development. Suboptimal supply of minerals (phosphorous, magnesium, zinc) and nutritional imbalances of fatty acids, vitamins (A, C and D) and amino acids are considered the main challenges in regard to skeletal malformations. The challenges related to bioavailability are further amplified with the introduction of vegetable meals, some of which are rich in antinutrients (e.g. phytic acid) that may further impair absorption. It is therefore important to completely understand the molecular and cellular events in bone development in salmon in order to deal with upcoming questions

Most of the knowledge currently available on cellular mechanisms for bone development is adopted from studies using mammalian species. However, information from teleosts, like zebrafish (Danio rerio), sea bass (Dicentrarchus labrax), sea bream (Sparus aurata) and Atlantic salmon and related in vitro studies, is emerging. Molecular tools like in situ hybridization, microarray, real time quantitative PCR, immunohistochemistry and cell culture systems have allowed researchers working with teleosts to do more comparative and functional studies. Also, transgenic model organisms, such as zebrafish, and in vitro transfection with reporter gene constructs are now being more common and will provide valuable information on processes involved in bone metabolism. Relevant examples include studies on gene expression of several bone and cartilage associated marker genes, such as bone morphogenetic protein 2 (BMP-2) (Rafael et al., 2006), osteocalcin (Wargelius et al., 2009; Ytteborg et al.,2010b), osteopontin (Fonseca et al., 2007), vitamin D receptor (Lock et al., 2009), parahyroid related hormone (Flanagan et al., 2000) and proteoglycans (Pedersen et al 2010; Conceição et al., 2008). The Sea bream vertebrae cell lines described by Braga et al. (2006) as well as two reports on zebrafish (DeLaurier et al., 2010; Kimmel et al., 2010) show the possibilities with fluorescent reporter gene constructs in bone research. The work developed during the last few years has provided clear evidence that fish can be adequate supplementary model systems to study bone and cartilage biology. Teleosts have been successfully used to analyze molecular and cellular mechanisms involved in different developmental pathways and revealed that the key genetic factors regulating lineage determination and differentiation of stem cells are conserved among vertebrates at the molecular level in both sequence and expression pattern (Kikuta et al., 2007; Shafizadeh et al., 2004; Nakashima et al., 2003; Aubin, 1998; Pinto et al., 2001; Renn et al., 2006; Wise et al., 2006; Ytteborg et al., 2010a). Due to the similar physiologic pathways and genetic 
background of fish and mammals, this alternative system is also an interesting model to unveil some of the molecular determinants of human bone related diseases and malformations, like osteogenesis imperfecta, degenerated disc disease, persistent notochordal canal and scoliosis (Gorman and Breden, 2007;Nissen et al., 2006;Fisher et al., 2003). A number of animal models have been used to explore the pathology of spinal deformities and revealed that vertebral pathology presents a complex but comparable cross species etiology. With regard to complex disorders in humans, multiple models are critical for the investigation and manipulation of etiological factors.

Fish systems could be of benefit to vertebral research because they exhibit a diverse range of deformities, are free from skeletal appendicles and substantial genomic resources have been developed for several species. Skeletal deformities in commercial salmon production have been recognized as a problem of obvious relevance to economy as well as animal welfare. Much effort has been put into understanding malformed development of Atlantic salmon vertebrae during the years due to the importance of this organism to the aquaculture industry. As a consequence, Atlantic salmon is emerging as an excellent model to study vertebral deformities and other relevant vertebral pathological states. In this review the current knowledge on the cellular and molecular mechanisms for skeletal homeostasis in the mature Atlantic salmon vertebrae is discussed. Further, the cellular mechanisms for differentiation and activation of osteoblasts and chondrocytes are described in relation to pathways for pathological development and discussed in the light of related pathological conditions in mammalian species.

\section{Cellular and molecular mechanisms controlling bone formation}

Bone formation basically occur via two mechanisms in both mammals and teleosts: mesenchymal stem cells (MSC) either differentiate directly into bone producing osteoblasts (intramembranous ossification) or by first forming a cartilaginous template secreted by chondrocytes which is later replaced by bone (endochondral ossification) (Erlebacher et al., 1995). However, similarities and differences in tissue structure between teleost and mammalian bone have been described (Witten et al., 2009; Huysseune et al., 2000). In general, fish possess rather few long bones with growth plate-like arrangements exhibiting typical endochondral bone formation as seen in mammals. In the Atlantic salmon vertebrae, compact bone of the amphicoel and trabeculae is formed directly through intramembranous ossification, whereas the arch centra are modelled through endochondral ossification. Both mechanisms lead to the formation of mineralized extracellular matrix (ECM), consisting of fibers, mainly collagen embedded in a matrix of proteoglycans (PGs) and proteins. An overview of the two different processes in the Atlantic salmon vertebra is shown in figure $2 \mathrm{a}$ and $b$.

\subsection{Linage determination and cellular differentiation}

The cellular lineage determination and differentiation of osteoblasts and chondrocytes from the MSC lineage are determined by a number of transcription factors, regulatory mechanisms, environmental conditions and mineral availability. The pathways are interconnected during vertebral formation and must be coordinated. In particular, the transcription factors Runx2, Osterix, Sox9, Twist and Mef2c have distinct functions both in the establishment of the vertebral bodies and later in the differentiation and maturation of 


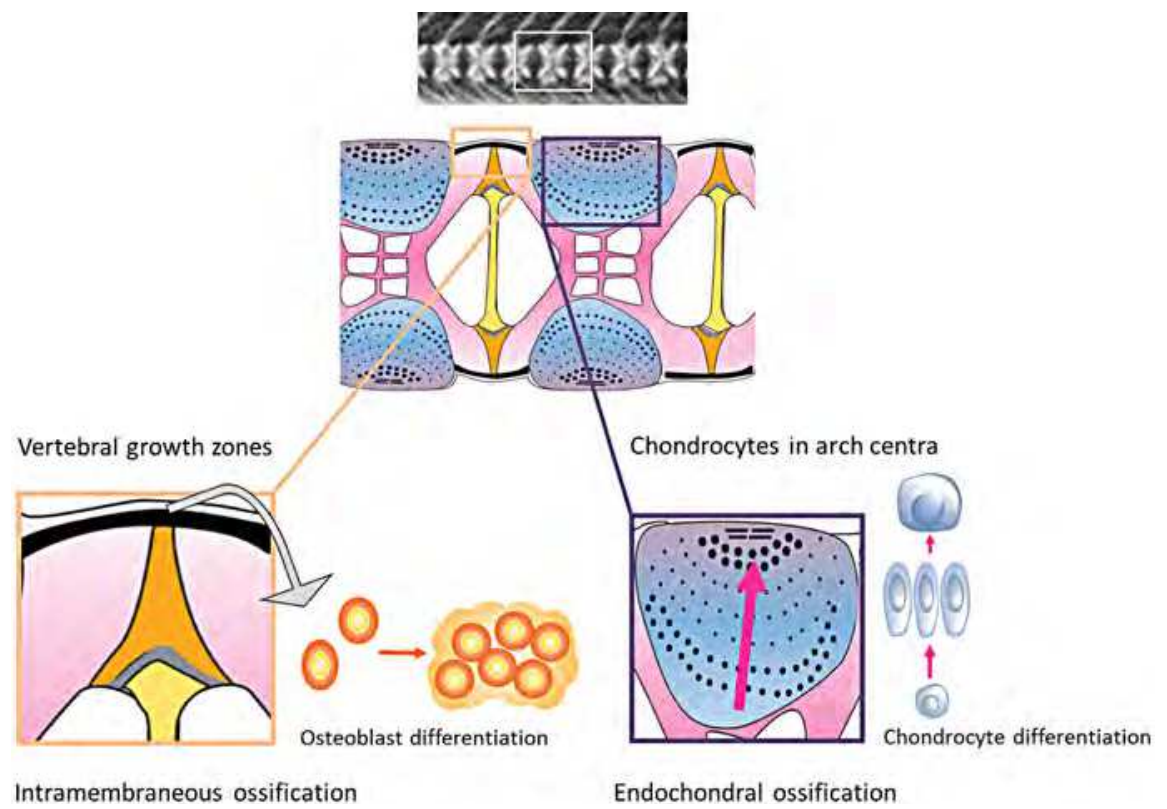

Fig. 2a. Overview of the intramembraneous and endochondral ossification in the Atlantic salmon vertebra. See the text below for details.
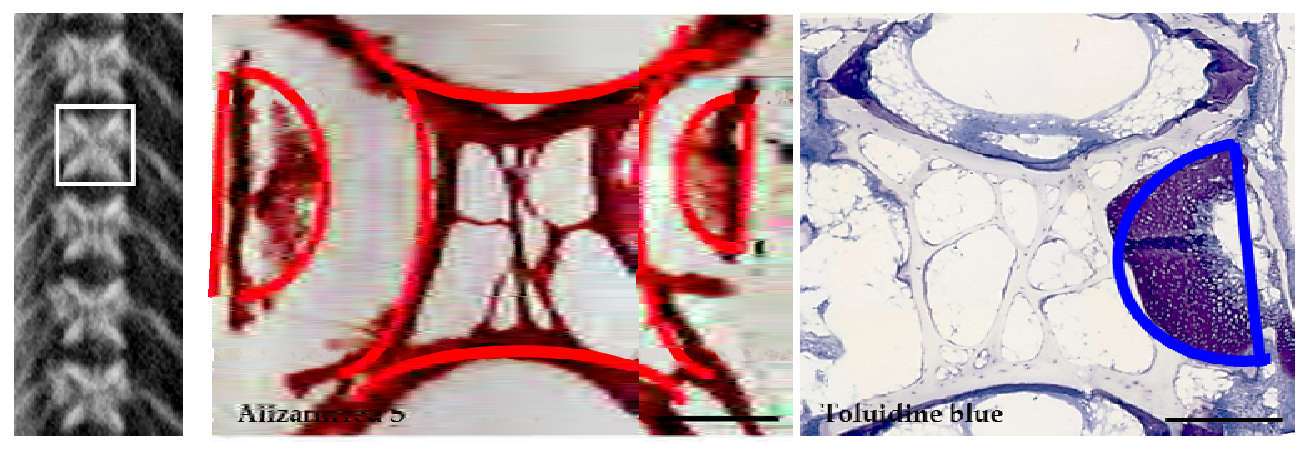

Fig. 2b. Bone and cartilage in the Atlantic salmon vertebra. Both endochondral and intramembraneous ossification leads to mineralized bone formation (red - Alizarin red S staining of bone in the centra and arches; blue - Toluidine blue staining of cartilage in the arches). See text below for further details on bone and cartilage formation. Vertebrae from $15 \mathrm{~g}$ fish, scale bar $=200 \mu \mathrm{m}$

specific skeletal cell types (Karsenty et al., 2009). Similarly, signaling molecules like bone morphogenetic proteins (Bmp2 and Bmp4) and hedgehog proteins (Ihh and Shh) play different roles both during cell differentiation and skeletal tissue ontogeny (Karp et al., 2000; Hogan et al., 1996; Spinella-Jaegle et al., 2001). Important signalling pathways that induce transcription of matrix producing and mineralizing genes in osteoblasts and chondrocytes include the downstream targets of Bmps; Runt-related transcription factor 2 (Runx2) the 
zinc finger containing transcription factor Osterix and Sex determining region $\mathrm{Y}$ box 9 (Sox9). Whereas Runx2 and Osterix activates genes in the osteoblastic lineage (Karsenty et al., 1999; Otto et al., 1997; Nakashima et al., 2002), Sox9 regulates transcription of chondrocytic genes (Bell et al., 1997).

The differentiation of MSC into mature osteoblasts involves several phases, which may be divided into three subsequent stages; commitment, extracellular matrix production and mineralization. Estrogen and 1,25-dihydroxy vitamin $\mathrm{D}_{3}$ are among the hormones shown to increase osteogenic differentiation via up-regulation of osteogenic growth factors, such as BMP2. Among the many transcription factors expressed early in osteogenesis, runx2 is noteworthy because it is required for bone formation and is an important early indicator of osteogenic capacity of cells. Downstream targets of Runx2 and Osterix include genes encoding both collagenous (e.g. Collagen $1 \alpha$ and $1 ß)$ and non-collagenous (e.g. Osteopontin, Osteocalcin, Osteonectin, Bone sialoprotein and Alp) proteins, which make osteoblasts capable of producing and mineralizing bone matrix (osteoid). In both teleosts and mammalian MSCs, alkaline phosphatase (Alp), colla and osteopontin serve as useful markers of early osteogenesis and the expression of these genes usually increases throughout maturation. Col1 is the major structural component of bone, whereas the noncollagenous proteins binds inorganic minerals and are involved in the mineralization process (Cowles et al., 1998; Ikeda et al., 1992; Bolander et al., 1988; Termine et al., 1981). Upon maturation, osteoblasts start secreting osteoid and mineralizing components, leading to direct formation of bone via the intramembraneous ossification pathway. The key markers involved in osteogenesis are shown in Figure 3.

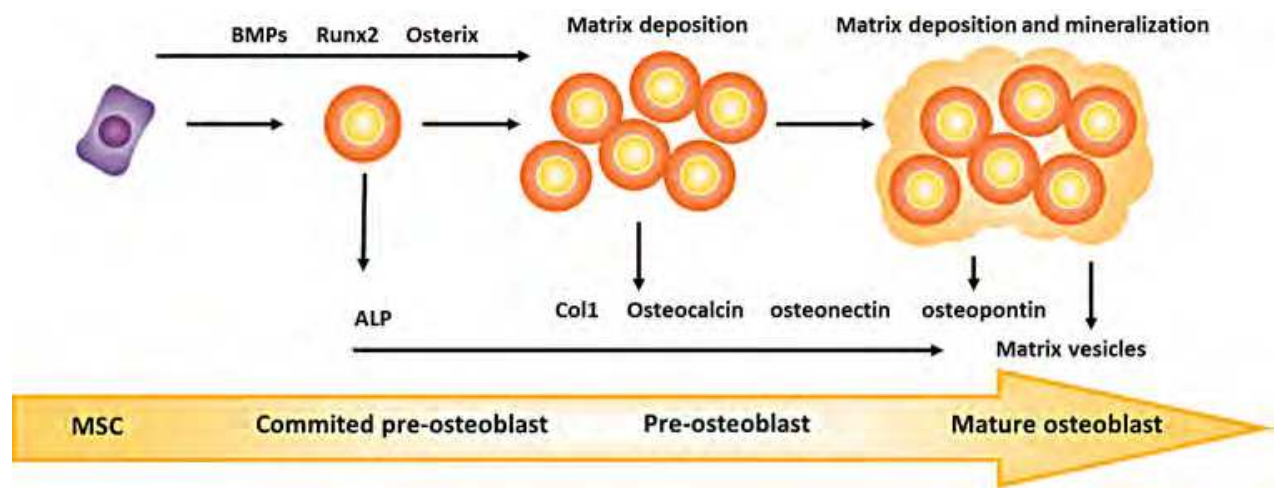

Fig. 3. Osteoblast differentiation, maturation and key factors involved. After commitment to the osteoblast lineage, matrix deposition starts. Mature osteoblasts are responsible for both osteoid production and mineralization. See text for details.

The chondrocytes undergo a more synchronized process of proliferation, differentiation and maturation so that three pronounced zones can be identified in the growing cartilage: resting, proliferating and hypertrophic zones (Hunziker et al., 1994). Chondrocytes in the resting zone are irregularly scattered in cartilage matrix, whereas chondrocytes in the proliferating and hypertrophic zones are arranged in columns. The chondrocytes in the resting zone serves as stem-like cells in the growth plate, stimulated by e.g. growth hormone $(\mathrm{GH})$ and insulin like growth factor (IGF). The proliferating zone is the region for active cell 
replication and chondrocytes in this zone are mostly devoted to cell cycle processes. Chondrocyte hypertrophy is the final step of chondrocyte maturation, regulated by the transcription factors Myocyte enhancer factor 2c (Mef2c) and Runx2 (Arnold et al., 2007; Kim et al., 1999). Parathyroid hormone related protein (PTHrP) and Ihh appear to play important roles in proliferating chondrocytes by maintaining cells in a proliferative condition, hence preventing chondrocyte hypertrophy. After commitment to the hypertrophic state, chondrocytes start expressing Col10 (Ytteborg et al., 2010b; Arnold et al., 2007), a unique component of the matrix produced by hypertrophic cells and extensively used as a marker for chondrocyte hypertrophy (Iyama et al., 1991). Once hypertrophy is reached, endochondral ossification can be initiated (Mackie et al., 2008). Hypertrophic chondrocytes induce angiogenesis by secreting angiogenetic factors, such as the Matrix metalloproteinases (Mmps) and Vascular endothelia growth factor (VEGF) so that osteoblasts and osteoclasts may enter via newly formed blood vessels (Blavier et al., 1995). The key markers involved in chondrogenesis are shown in Figure 4.

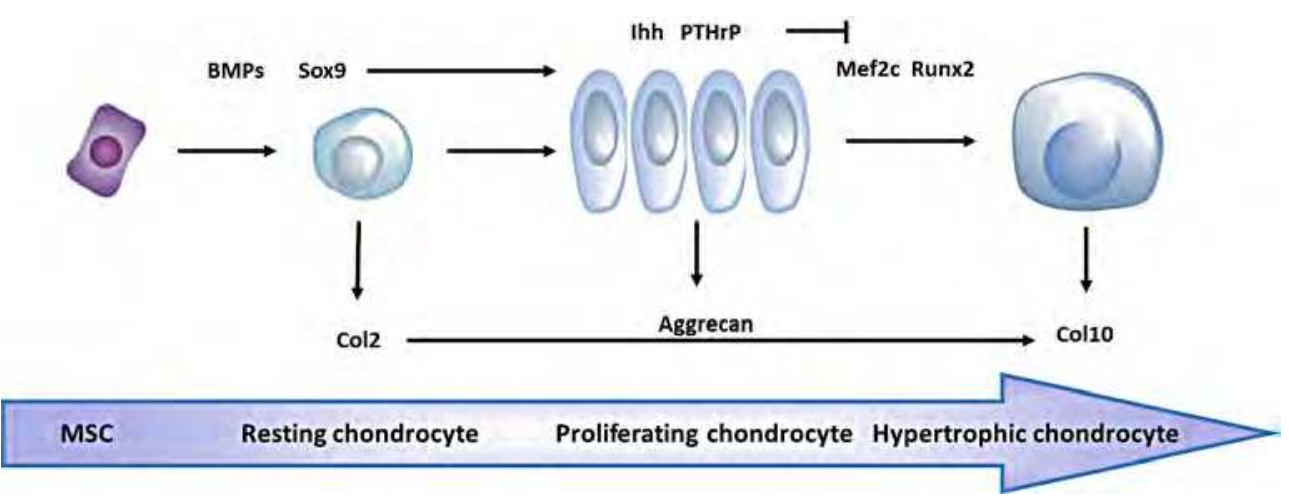

Fig. 4. Chondrocytic differentiation, maturation and key factors involved. Resting, proliferating and hypertrophic chondrocytes are clearly visible as zones in the growth plate. See text for details.

Osteoclasts are cells involved in removing damaged bone, repair mechanisms, mineral homeostasis and replacement of cartilage with bone, both in mammals (review in Boyle et al., 2003) and teleosts (reviewed in Witten et al., 2009). Osteoclasts provide an acidic environment where mineralized matrix may be dissolved through secretion of cathepsins, mmps and tartrate resistante acid phosphatase (TRAP) (Delaisse et al., 2003; Motyckova et al., 2001; Ortega et al., 2003; Engsig et al., 2000). As in mammals, osteoclasts in Atlantic salmon are multinucleated and the mechanisms involved in activation and differentiation of osteoclasts are conserved (review in Witten et al., 2009). Mononuclear cells respond to macrophage colony stimulating factor (M-CSF) produced by nearby stromal cells and osteoblasts, through activation of c-fms, the receptor for M-CSF (Wiktorjedrzejczak et al., 1990; Yoshida et al., 1990). The other signaling system essential for osteoclast differentiation is triggered when receptor activator of nuclear factor kappa ( $\mathrm{k}$ ) B ligand (RANKL), a member of the tumor necrosis factor (TNF) family, activates its receptor RANK (reviewed in Collin-Osdoy et al., 2004). Among the downstream genes of RANKL are genes directly ivolved osteoclast function (e.g. TRAP and Cathepsin K). The key markers involved in 
osteoclastogenesis are shown in Figure 5. In addition, mononucleated osteoclasts are also found in both mammals and teleosts and are considered to participate in minor, fine tuning bone resorption (Witten et al., 2009). However, since teleost lack haemapoietic tissue in bone marrow, the question of the origin of these cells remains unknown. In the vertebrae of Atlantic salmon, multinucleated osteoclasts have been identified in the arch centra and trabeculae but not in the compact bone of the amphicoel (Witten et al., 2009).

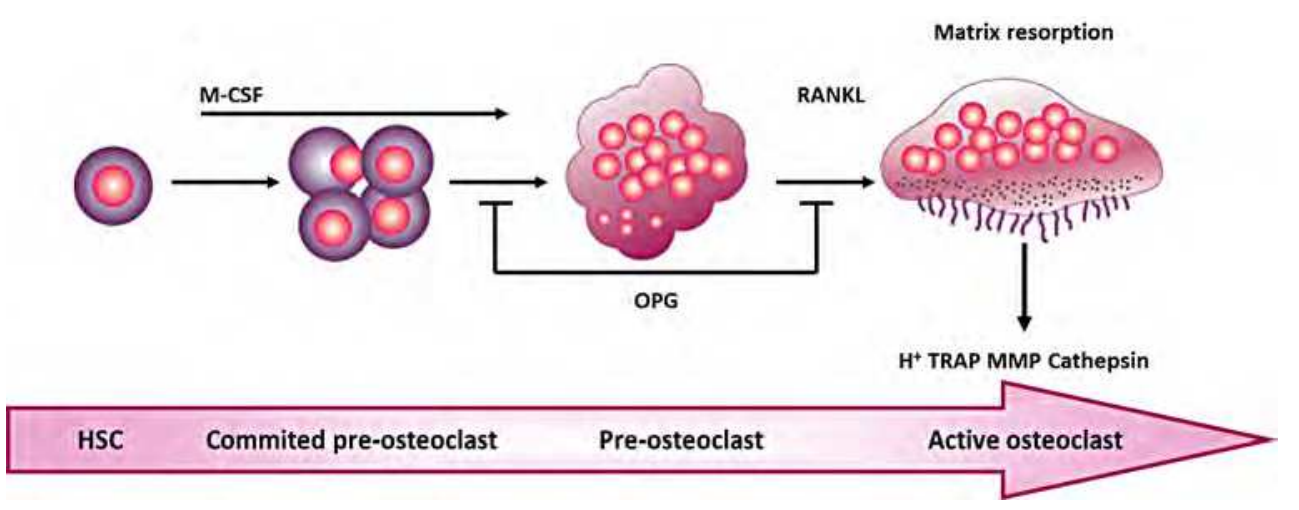

Fig. 5. Osteoclast differentiation, maturation and key factors involved. Fully mature osteoclasts are able to dissolve bone. See text for details.

\subsection{Matrix mineralization}

Skeletal formation and growth occurs as a result of mineralization of ECM. A time lag where collagen synthesis decreases and mineralization increase appears to be required for allowing modifications of the osteoid so that it is able to support mineralization and hydroxyapatite $\left(\mathrm{Ca}_{10}\left[\mathrm{PO}_{4}\right]^{6}[\mathrm{OH}]^{2}\right)$ formation (Hernandez et al., 2000). Mineralization of both bone and cartilage occurs by deposition of inorganic hydroxyapatite crystals inthe ECM. This process has not yet been described in teleosts. In mammals, the initiating step of hydroxyapatite formation occurs in ECM vesicles secreted from mature osteoblasts (Anderson et al., 2005, 1996, 1995). These vesicles create an environment where deposition of minerals (mainly Ca2+ and $\mathrm{P}_{\mathrm{i}}$ ) occurs and hydroxyapatite is produced, a process involving proteins like Annexins and Alp (Balcerzak et al., 2003; Kirsch et al., 2005). The attachment of the vesicles to bone is not well understood, but Alp and Annexin in the vesicle membrane are reported to anchor to collagen fibrils ( $\mathrm{Wu}$ et al., 1991). Vesicle formation is followed by the linking of hydroxyapatite crystals to ECM components (Balcerzak et al., 2003) using the $\mathrm{Ca}^{2+}$ and hydroxyapatite binding properties of Osteonectin, Osteopontin, Osteocalcin and Bone sialoprotein (Hoffmann et al., 1996; Pinto et al., 2001; Furie et al., 1991). Hypertrophic chondrocytes are also capable of initiating calcification processes by releasing similar matrix vesicles as osteoblasts and it has been suggested that hypertrophic chondrocytes may participate actively in bone formation (Anderson et al., 1975; Kirsch et al., 1997). Moreover, hypertrophic chondrocytes from both mammals and teleosts express genes like osteocalcin, osteonectin and alp (Ytteborg et al., 2010b; Ishizeki et al., 1996; Lian et al., 1993). Cancedda et al. (1992) showed that hypertrophic chondrocytes from chicken can be induced to obtain a strictly osteoblastic phenotype in vitro. These findings are supported by Yasui et al. (1997) 
who suggested that hypertrophic chondrocytes are able to trans-differentiate into osteoblasts and produce bone through a process called trans-chondroid ossification. More than 10 different forms of cartilage and several other tissues with histological characteristics between bone and cartilage have so far been identified in fish (Huysseune et al., 1986; Huysseune et al., 1990). This makes bone studies in Atlantic salmon more complicated, as strict lines between cell types and distinct borders between tissue structures are difficult to define. However, intermediate tissue is instructive due to the many molecular pathways and cellular adaptations during pathological development and normal growth.

\section{Pipeline for studying vertebral development}

Bone deformities in Atlantic salmon are a complex problem, which may have diverse causes, acting either one by one or in combination, hence, a number of different tools are important to establish in order to cover different mechanisms involved in their development. The pipeline for studying bone development in teleosts is shown in figure 6 . In vertebrates, both bone and cartilaginous structures coexist during development of the vertebral column and both tissues are built up mainly of the organic ECM. Cartilage and bone cellular activity largely depends on the interaction with ECM components. ECM components regulate cell growth and differentiation by interacting with growth factors and enzymes, provide the tissue with mechanical strength and resilience and constitute the template for mineralization during development of the vertebral column. The composition and structure of molecules in the ECM are shown to play pivotal roles in bone formation and changes therein may result in deformities in the spine of both mammals and teleosts (Pedersen et al., 2010). Radiography, or the use of X-rays for analysis, is the preferred method for fish skeletal deformity diagnostics. X-rays have enough energy to penetrate soft tissues, but not bone and other hard substances. Moreover radiography thus allows the creation of a negative image of the skeletal structures of the fish, which allows the evaluation of calcification level and for identification of pathology in the bones, without cutting into or even killing the fish. However, fish radiography has its limits and it is difficult to diagnose fish before the deformity has developed. More sensitive techniques are therefore necessary. So far in vivo trials with Atlantic salmon using different temperatures and light regimes, water speed for studying the effect of training and feeding trials using custom-made feeds for studying mineral and vitamin components has been applied for deformity studies. In addition to radiography and measuring rate of development and growth, essential minerals have been followed from uptake and secretion in the intestines using quantitative real time PCR, to incorporation in the bone matrix using mineral analysis and Fourier Transform InfraRed (FT-IR), histological staining techniques and screening techniques such as microarray. Important pathways for cellular differentiation of bone and cartilage have been followed using gene expressional tools, like quantitative real time PCR, in situ hybridization and immunohistochemistry. In a recent puplication, (Ytteborg et al., 2010b), it was shown by using molecular markers and gene transcription techniques, that fish susceptible for developing vertebral fusions could be detected already at $2 \mathrm{~g}$ size. Atlantic salmon in vitro based systems are also developed, where cellular differentiation and lineage determination can be studied in more controlled environments (Ytteborg et al, 2010a). Combining radiography, histological staining techniques and molecular tools has led to a more complete understanding of how normal and pathological bone formation in Atlantic salmon progress and opens up for prospective advanced functional studies in 


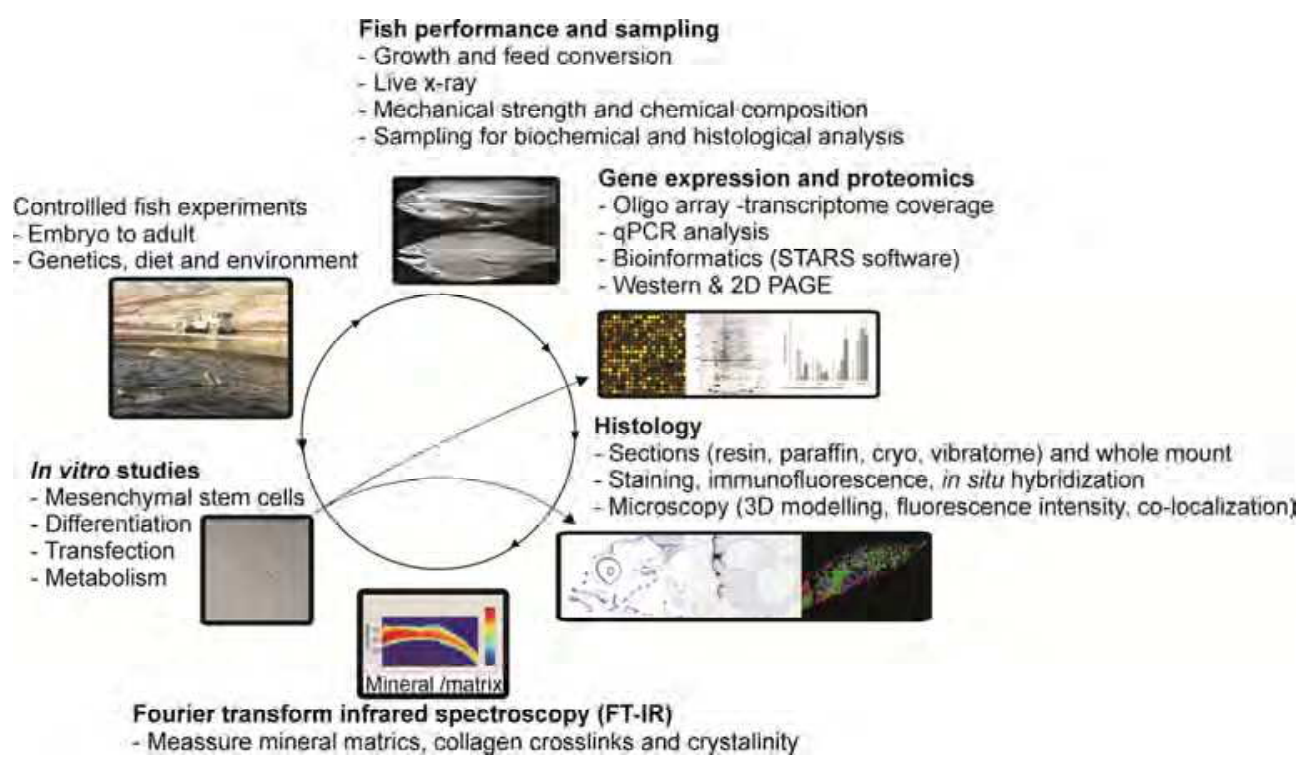

Fig. 6. Pipeline for studying vertebral development.

commercial teleosts species. Importantly, management control of deformities and health in general demands precise tools and knowledge to depict any problem as early as possible in the production line. The reliable correlation between defined skeletal markers and the risk of developing vertebral deformities has indicated that these genes can be developed as prognostic markers and further be used to investigate how the progression of skeletogenesis is modulated in response to other stimuli.

\section{The teleost vertebra}

The vertebral column is the defining feature of all vertebrates, composed of an alternating pattern of vertebral bodies (centra) and intervertebral regions. While centra give support and strength to the organism, intervertebral regions provide flexibility. The segmented pattern of the spine is established during embryogenesis when the precursors of the vertebrae, the somites, are formed (review in Brand-Saberi et al., 2000). The mature Atlantic salmon vertebra consists of approximately 58 vertebral bodies with neural and heamal arches protruding from the top and bottom of the centrum, respectively (Kacem et al., 1998). Grotmol and co-workers (Grotmol et al., 2006, 2005, 2003) have previously described the early development of the Atlantic salmon vertebrae in details. However, few studies have defined the nutritional needs or described the functions needed to keep continuous growth, remodelling and homeostasis in the mature vertebrae. An overview of the Atlantic salmon vertebra features is shown in figure 7.

\subsection{The intervertebral regions}

The notochord is found in embryos of all chordates, being well conserved between species as the forerunner of the spinal column. However, whereas only remnants of the notochord 

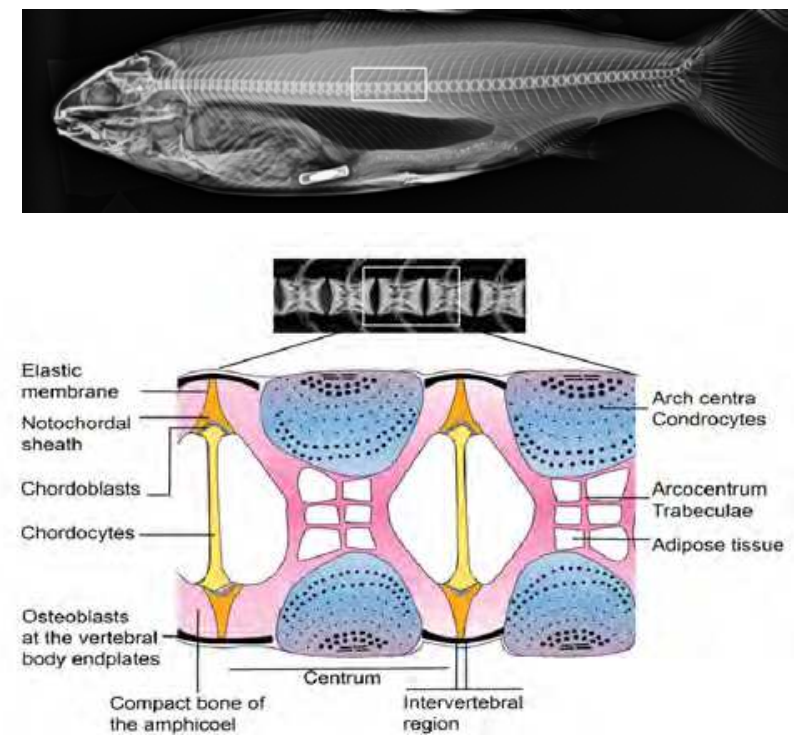

Fig. 7. Overview of the Atlantic salmon vertebra.

exist in the mammalian intervertebral disc (IVD) between adjacent vertebrae (Walmsley et al., 2009), the notochord persists throughout all life stages and throughout the entire length of the fully developed vertebral column in many teleosts, including Atlantic salmon. The morphology and function of the notochord of the mature vertebrae has not been thoroughly described. However, the layers and cell types found at early larval stages persist throughout all life stages in the salmonides. Hence, the mature notochord of Atlantic salmon consists of a core of chordocytes, a layer of chordoblasts, an acellular fibrous sheath and an outer elastic membrane (Grotmol et al., 2006). The chordoblasts continue to divide throughout life in accordance with sustained notochordal growth (Grotmol et al., 2006) and maturate into chordocytes, containing large fluid filled vacuoles (Adams et al., 1990; Glickman et al., 2003; Nordvik et al., 2005). The chordoblasts also produce the basal membrane and ECM components of the notochordal sheath, which in both mammals and teleosts like Atlantic salmon, has been shown to consist of mainly Col2 fibrils (Domowicz et al., 1995;Linsenma et al., 1973; Sandell et al., 1994). In mammals, the remnants of the notochord, the chordoblasts and their subsequent matrix, develop into the intervertebral discs (IVDs), which separate the vertebral bodies. The annulus fibrosus (AF) surrounding the nucleus pulposus (NP) of mammalian discs consists of overlapping collagen and elastin fibrils, forming transversing bands crossing the joint in opposite directions, hence, stabilizing and supporting the intervertebral regions. The NP consists of a fluid filled matrix which distributes the hydraulic pressure in all directions within each disc under compressive loads. Similarly in teleosts, the helical geometry shift between adjacent collagen lamella in the acellular notochordal sheath restricts expansion of the vacuolated chordocytes (Grotmol et al., 2005; Grotmol et al., 2006; Koehl et al., 2000). The elastic membrane surrounding the notochordal sheath has a thickened structure in the intervertebral regions, further contributing to increased strength in these regions. At more mature stages, the notochordal sheath consists of folded structures (Ytteborg et al., 2010d), which may be the consequence of compressions 
of the notochordal sheath upon formation and mineralization of the centra. As the crosshelical architecture of parallel Col2 fibrils probably is important for flexural stiffness of the larval body during development (Grotmol et al., 2006) the folded pattern may contribute to increased flexibility and normal functioning of the mature spinal column.

In addition to its structural role, the notochord secretes factors to surrounding tissues and contributes to vertebral patterning during embryogenesis (Cleaver et al., 2001; Fleming et al., 2004). The role of the notochord in patterning of the somites is known from several studies from chicken, mouse and zebrafish, in which secretion of Sonic hedgehog (Shh) from the notochord appears to be essential both for somite survival during the early somitogenesis and for induction of the sclerotome during later somitogenesis (review in Monsoro-Burq et al., 2005). In vertebrate species with limited growth, such as humans, the notochord ceases its regulating role for vertebral development as part of the normal ontogeny, followed by the transformation of notochordal tissue into cartilage (Hunter et al., 2003; Oegema et al., 2002). In Atlantic salmon, however, the notochord should fulfil its regulating role for vertebral body differentiation throughout life, since salmon and other fish species do not stop growing. Immunohistochemistry with the proteoglycan component Perlecan has revealed that this protein is abundantly present in the notochordal sheath of Atlantic salmon (Ytteborg et al., 2010d). Perlecan has structural roles in mammalian cartilage and IVD (Sivan et al., 2006) and is important for proper establishment of basement membranes in different vertebrates including teleosts (Parsons et al., 2002; Aviezer et al., 1994). An interesting aspect of Perlecan is its link to nutritional transportation over the notochordal sheath. Parsons et al. (2002) have previous suggested similarities between the structural role of the teleost notochordal sheath and the mammalian glomerular kidney membrane (GBM). GBM is an important part of the filtration machinery in the kidneys and involved in hydrostatic pressure maintenance (Timpl et al., 1996). The heparan sulfate chains of perlecan have further been shown to play important roles in glomerular filtration (Morita et al., 2005) and to be involved in diffusion of nutrients during tooth development in mice (Ida-Yonemochi et al., 2005). The mammalian IVD basically relies on diffusion for nutrient supplies and removal of waste products. As no evidences for vascularization of the Atlantic salmon notochord exists today, it seems likely that a similar transportation system must apply for the vacuolated chordocytes in the notochord core.

\subsection{The centra}

The Atlantic salmon spinal column is formed directly in bone, in contrasts to the formation of the vertebrae of avian and mammalian species, which are first formed in cartilage (Arratia et al., 2001; Smith et al., 2009). At early stages, the precursors for the osteoblasts are situated on the external elastic membrane only interrupted by the neural and haemal arch cartilages. The segmentation process leading to formation of vertebral and intervertebral regions starts with the formation of the chordacentra, where matrix in the outer half of the notochordal sheath becomes mineralized (Fleming et al., 2004; Arratia et al., 2001; Laerm et al., 1976; Grotmol et al., 2003). Osteoblast at the vertebral growth zones and osteoblasts lining the trabeculae are involved in intramembraneous ossification. Denser osteoblast populations are located along the cranial and caudal rims of each vertebral body, leading to the biconid hour-glass shaped vertebra. In situ hybridization has confirmed transcription of osteogenic marker genes like runx2, col1a, osteocalcin and osteonectin in these populations at mature stages in Atlantic salmon ontogeny, confirming their actively involvement in osteoid 
production throughout life (Krossøy et al., 2009; Ytteborg et al., 2010b and c), shown in figure 8. In the arch centra of Atlantic salmon, in situ hybridization have identified subpopulations of chondrocytes corresponding to the resting, proliferating and hypertrophic chondrocytes described in mammals (Ytteborg et al., 2010b; Hunziker et al., 1994). Chondrogenic marker genes, like col2a, col10a, sox 9 and mef $2 c$, are characteristic for specific maturation zones and have been used to characterize the maturation process in the arches of Atlantic salmon (Ytteborg et al., 2010b). TRAP secreting osteoclasts has further been identified at the ossifying borders of the salmon arch centra, marking the ossification front during endochondral ossification (Witten et al., 2009, Helland et al., 2006; Ytteborg et al., 2010c). In the vertebrae of Atlantic salmon, multinucleated osteoclasts have also been identified in the trabeculae but not in the compact bone of the amphicoel (Witten et al., 2009). As the vertebra grow through the activity of osteoblasts located along the distal ridges, the trabeculae becomes more branched and filled with adipose tissue. After finishing shaping the scaffold for the vertebral bodies, the Atlantic salmon vertebrae continue to grow throughout life (Nordvik et al., 2005). Compared to mammals, where bone is constantly remodeled, the shape and constant growth of the salmon vertebrae have indicated that the need for bone remodeling is scarce. During stressful or unfavorable conditions or during periods of rapid growth, the mammalian skeleton is used as a mineral reservoir, where minerals are released through the activity from the osteoclasts. In Atlantic salmon however, such reservoirs are mostly found in the scales. Experiments have shown that long-term

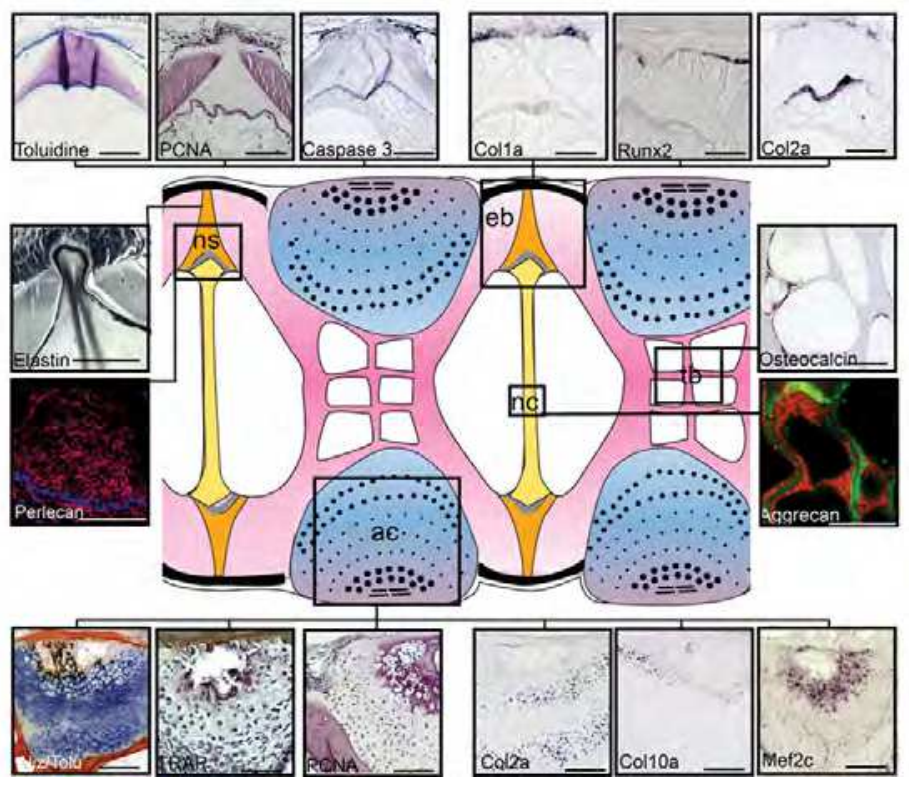

Fig. 8. Overview of histological, immunohistochemical and molecular findings in nondeformed vertebrae. Vertebral endbones (top): Toluidine, PCNA, Caspase 3, col1a, runx2, col2a Elastin in elastic membrane (left), Perlecan in notochordal sheath (left). Osteocalcin in trabeculae (right). Aggrecan in chordocytes (right) Arch centra (bottom): Alizarin red/Toluidine blue, TRAP, PCNA, col2a, col10a, mef2c. Trabeculae, tb; Notochordal sheath, ns; Notochord, nc; End bone, eb; Arch centra, ac. Scale bare $=100 \mu \mathrm{m}$. 
stressful conditions rather manifests in salmon as overall improper bone formation and cellular disturbances rather than increased bone resorption. This has been shown through $\mathrm{x}-$ ray visualization of lower radiodensity (e.g. in "ghost" and "hyperdence" vertebrae), development of "soft" bone phenotype, transcriptional analysis (e.g. reduced transcription of genes involved in production and mineralization of ECM) and immunohistochemistry showing disturbed cell cycling (e.g. using PCNA antibodies) in vertebrae not yet possessing skeletal malformations. However, these disturbances might further develop into vertebral deformities at later stages.

\section{Vertebral deformities}

Deformities in the spinal column have been observed in a diverse array of vertebrates and a number of causatives have been suggested. Spinal disorders are a major concern for human health and often related to painful conditions (Freemont et al., 2009). Spinal lesions observed in wild animals, such as brown bear, sandtiger shark and smallmouth bass are occasionally found and often reflect environmental problems (Preziosi et al., 2006; Bengtsson et al., 1979; Vandenavyle et al., 1989; Wagner et al., 2005). Deformities in domesticated animals like chicken, broilers, pigs and farmed fish are recognized as a reoccurring problem in intensive production system and represent both ethical and economical challenges (Berg et al., 2006; Hammond et al., 2007; Julian et al., 1998; Reiland et al., 1978; Sullivan et al., 2007). Fish with spinal deformities, such as salmon, trout, cod, halibut, sea bass and sea bream, do not swim efficiently, are less capable of acquiring food, are at a greater risk of predation and are more susceptible to physiological imbalance, in addition to being down-graded at slaughter (Silverstone et al., 2002). Most deformity studies in teleosts have been largely descriptive and primarily performed to reveal factors contributing to increased occurrence of skeletal deformities, e.g. genetics, infections, fast growth, light regimes, vaccination, water current and quality, pollution, malnutrition and elevated temperatures (Berg et al., 2006; Berntssen et al., 2003; Cahu et al., 2003; Divanach et al., 1997; Gjerde et al., 2005; Koumoundouros et al., 2001; Lall et al., 2007; Madsen et al., 2000; Roy et al., 2002; Vagsholm et al., 1998). Spinal deformities in Atlantic salmon have been intensively studied during the past years due to the importance of this specie to the aquaculture industry. Bone deformities in Atlantic salmon are a complex problem, which may have diverse causes that may act alone or in combination. Among these causes of bone deformities, the effect of temperature stress during the early developmental stages is best documented (Ytteborg et al., 2010a,b; Wargelius et al,. 2005). Malformations later in life are often related to abnormal nutritional preferences, malnutrition or fast growth. Until recently, the molecular development of spinal deformities in fish has received relatively little attention and few deformities have been explored beyond the level of association with particular causative factors. However, accumulated studies on intensive production regimes and incidence of deformities have been followed by more and more advanced studies on vertebral development and bone biology. Below is the current state of knowledge on cellular mechanisms for pathological bone development. In figure 9, major causatives, radiography and histological staining of normal and deformed salmon is shown.

\subsection{Cellular mechanisms behind weakened bone structures and development}

Conditions that accompany fast growth in farmed animals, e.g. light and feeding regimes, elevated temperatures and breeding, are linked to increased numbers of spinal deformities 

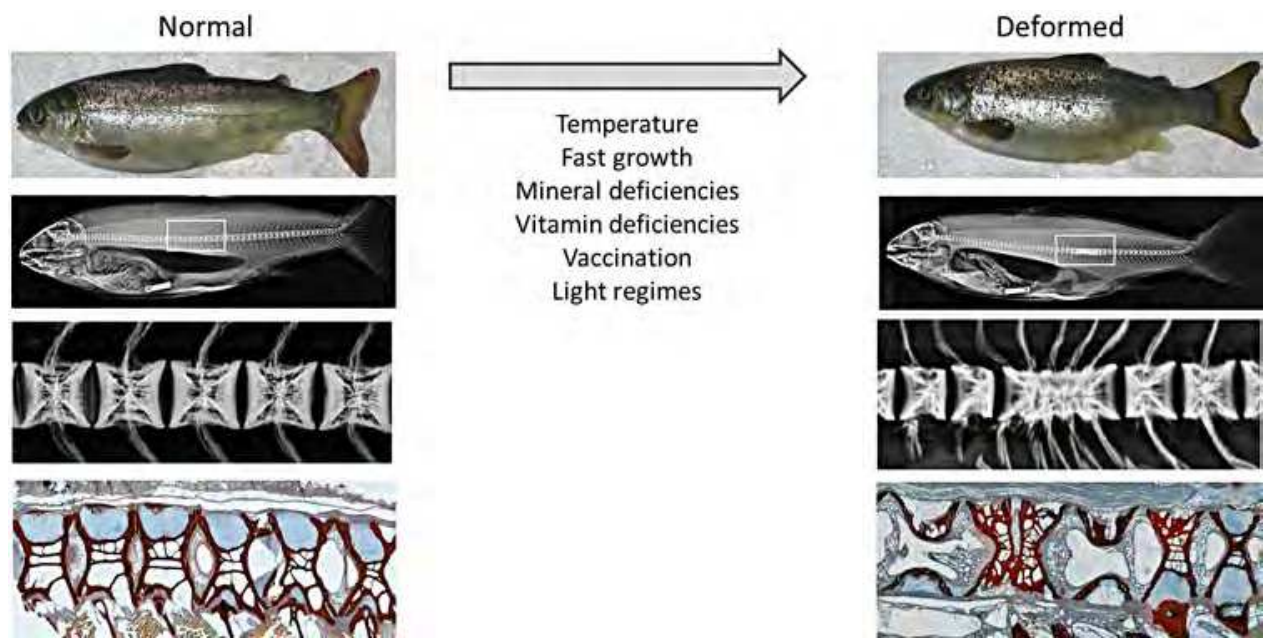

Fig. 9. Normal (left) and deformed (right) Atlantic salmon. From the top: photography of the fish, radiographic image, enlarged radiography, Alizarine red S and Tolouidine blue double staining.

(Julian et al., 1998; Reiland et al., 1978; Wargelius et al., 2009). Fast growing Atlantic salmon has been shown to develop soft, low mineralized, bone compared to fish with lower growth rates (Fjelldal et al., 2006) and to have an increased risk of developing vertebral deformities (Fjelldal et al., 2007; Fjelldal et al., 2005). In fast growing Atlantic salmon, elevated muscle mass exercise pressure on under-calcified bone that increases the mechanical pressure, which might trigger formation of intermediate tissues and malformations (Witten et al., 2005). Comparative studies have been performed in commercially farmed chicken, which are the product of long-term selective breeding for high growth rates (Leterrier et al., 1992). Fast growing chicken have weaker bone structures and increased rates of skeletal abnormalities than slower growing broilers, which reduces the bone's ability to adapt to the higher loads induced by the increasing body weight (Rawlinson et al., 2009). In Atlantic salmon, however, high genetic growth rates have not been correlated to increased rates of deformities (Gjerde et al., 2005). To fulfil the requirements for bone mineralization, fast growing animals needs to assimilate a higher proportion of the mineral intake (Hernandez et al., 2000). However, knowledge concerning mineral uptake and transportation in the fish intestines are lacking and needs to be studied further. The current change in fish feed production, switching to a vegetable based lipid diet, may further change the intestinal uptake of minerals, vitamins and amino acids (Jutfelt et al., 2007). Achieving predictable production of high-quality fish that perform well later in life therefore requires a high level of control of various factors influencing normal development and growth during early phases of life. Understanding the interactions between dietary mineral levels, $n-6 / n-3$ fatty acid ratios, bioavailability, growth rate, temperature and intestinal uptake is imperative to be able to balance diet composition and use available feed ingredients adequately.

At the cellular level, a general trade-off between proliferation and differentiation has been suggested as a cause for delayed skeletal development in fast growing species of birds (Arendt et al., 2000; Rawlinson et al., 2009). It has further been suggested that during rapid 
growth the time required for bone matrix to be produced and mineralized may be reduced to a critical level (Hernandez et al, 2000); hence development of a soft bone phenotype. This causative relation has been suggested for fast growing under-yearling Atlantic salmon smolt that has a higher incidence of vertebral deformities than slower growing yearling smolt (Fjelldal et al., 2006). Temperature and light regimes are factors shown to speed up developmental rate in Atlantic salmon, but also to delay production of osteoid. It therefore seems that bone remodeling in Atlantic salmon is generally sensitive to elevated growth rates (Ytteborg et al., 2010a). Osteoblasts and chondrocytes are cell types producing large quantities of ECM and may therefore be particularly sensitive to stressful conditions, due to reduced normal protein synthesis (Tsang et al., 2007; Haynes et al., 2004). Quantification of mRNA in vertebrae from fast growing Atlantic salmon has revealed a reduced transcription of important genes encoding structural proteins taking part in the bone matrix and mineralization, e.g. col1a1, osteocalcin and osteonectin (Ytteborg et al., 2010b). Furthermore, generally weaker in situ hybridization signals were detected for probes targeting these ECM transcripts in areas where intramembranous ossification takes place. These findings further correlated to an impaired mineralization and supported the assumption that disturbances in bone formation constitute an important part of the mechanisms involved in soft bone formation. These observations are further consistent with an Atlantic salmon osteoblast in vitro experiment, where long-term $16^{\circ} \mathrm{C}$ heat exposed cells showed a decreased transcription of alp, colla1 and osteocalcin. Based on in vitro and in vivo results it seems that Atlantic salmon osteoblasts may be particularly sensitive to elevated temperatures during the early stages of differentiation.

In mammals and teleosts like Atlantic salmon, elevated temperatures and fast growth may also interrupt the normal chondrocytic differentiation pattern and delay endochondral bone formation, further weakening the bony structures (Tsang et al., 2007). A number of studies have linked skeletal malformations to disturbances in chondrocytic maturation (Kieswetter et al., 1997; Farquharson et al., 2000; Julian et al., 1998). Recent results have suggested that fast growth caused by elevated temperatures leads to an arrest prior to the final maturation of chondrocytes in the Atlantic salmon vertebral arch centra (Ytteborg et al., 2010c). Morphological studies of the arch centra of juvenile Atlantic salmon reared under intensive temperatures have identified chondrocytes with a distorted maturation pattern and an increased zone of hypertrophic chondrocytes (Ytteborg et al., 2010c). In this study, an increased zone of hypertrophic chondrocytes correlated with increased transcription of hypertrophic marker genes such as col10a1 and mef2c. Fast growing chickens are also characterized by disturbed chondrocytic maturation where cartilage do not mature enough to ossify (Julian et al., 2005; Farquharson et al., 2000) and increased mechanical load is associated with an increased hypertrophic zone in the growth plate of rat ulnae along with a suppressed mineralization rate (Robling et al., 2001; Ohashi et al., 2002). Furthermore, mammalian osteoclasts are temperature sensitive and hypothermic conditions may stimulate their activity (Patel et al., 2009). Similar observations have been described in Atlantic salmon where no TRAP activity was observed in the arch centra of fish reared at intensive temperatures. Also transcription of osteoclast associated marker genes, like Mmps and Cathepsin K was reduced (Ytteborg et al., 2010c). Absence of Mmps may cause delays in endochondral ossification and runx2 deficiency may inhibit mmp expression and lead to mild disturbances of chondrocyte differentiation (Inada et al., 1999; Kirsch et al., 1997; Pratap, 2005). Disturbances in chondrocytic maturation and endochondral ossification will 
overall weaken the vertebrae, and may be an explanation for wrinkled and shortened ribs observed in Atlantic salmon suffering from P deficiency (reviewed in Sugiura et al 2005).

Overall, both bone and cartilage formation seems disturbed during fast growth and may equally contribute to weakened skeletal structures. In Atlantic salmon, experiments have indicated that during rapid growth, both endochondral and intramembraneous ossification is affected. Moreover, fast growth leading to weakened bone and cartilage structures at juvenile stages increases the risk of developing severe deformities later in ontogeny. This might be a result of local cellular compensation and an effort to restore and strengthen a weakened area in the vertebrae, as described in the next chapter.

\subsection{Cellular mechanisms behind vertebral deformities}

Witten et al. (2009) recently published a survey on commonly observed vertebral malformations in Atlantic salmon which included different grades and combinations of platyspondyly (compressions), ankylosis (fusions), lordosis ( $V$-shaped vertebral column), kyphosis ( $\wedge$-shaped vertebral column) and scoliosis (S-shaped vertebral column). Histological characterization of compressions and fusions have described shape alterations of vertebral body endplates, reduced intervertebral space, transformation of intervertebral notochord tissue into cartilage, mineralization of the intervertebral cartilage and replacement of intervertebral cartilage by bone (Witten et al., 2005; Kvellestad et al., 2000; Witten et al., 2006), independent of the factor inducing the malformation. Changes in transcriptional processes in osteoblasts and chondrocytes from both mammals and teleosts are involved in pathological vertebral formation (Hammond et al., 2007; Breen et al., 1999; Wargelius et al., 2005). The development of vertebral fusions is a dynamic process but recent publications have shown that the underlying cellular and molecular mechanisms may be summarized as four key events (Ytteborg et al., 2010a, b and c). These events are illustrated in figure 10 and described in the text below.

\section{I: Disorganization}

The initiation of the fusion process includes disorganization and proliferation of osteoblasts and chordoblasts. Osteoblasts at the growth zones of the vertebral body endplates have a markedly increased cell proliferation rate and the growth zones extend spatially along the rims of fusing vertebral bodies. As the intervertebral space narrows, proliferating chordoblasts and denser packet chordocytes appear. With a progressing pathology, proliferating chordoblasts occupy most of the intervertebral space and vacuolated chordocytes disappear.

\section{II: Metaplastic shift}

Proliferating cells at the border between the osteoblast growth zones and the arch centra show a transcriptional shift, where co-transcription of osteogenic (col1a, runx2, osteocalcin and osteonectin) and chondrogenic (col2a, mef2c and col10a) marker genes are prominent. The marked border between the osteoblast growth zones and the chondrocytic areas connected to the arches becomes less distinct, as proliferating cells and chondrocytes blend through an intermediate zone. A similar shift is found in the notochord where co-transcription of genes such as col2a, sox9, colla and runx2 increase with proliferation of chordoblasts. In the central notochord of developing fusions, hyperdense regions of denser packet chordocytes lacking vacuoles appear as the number of proliferating cell increase. 


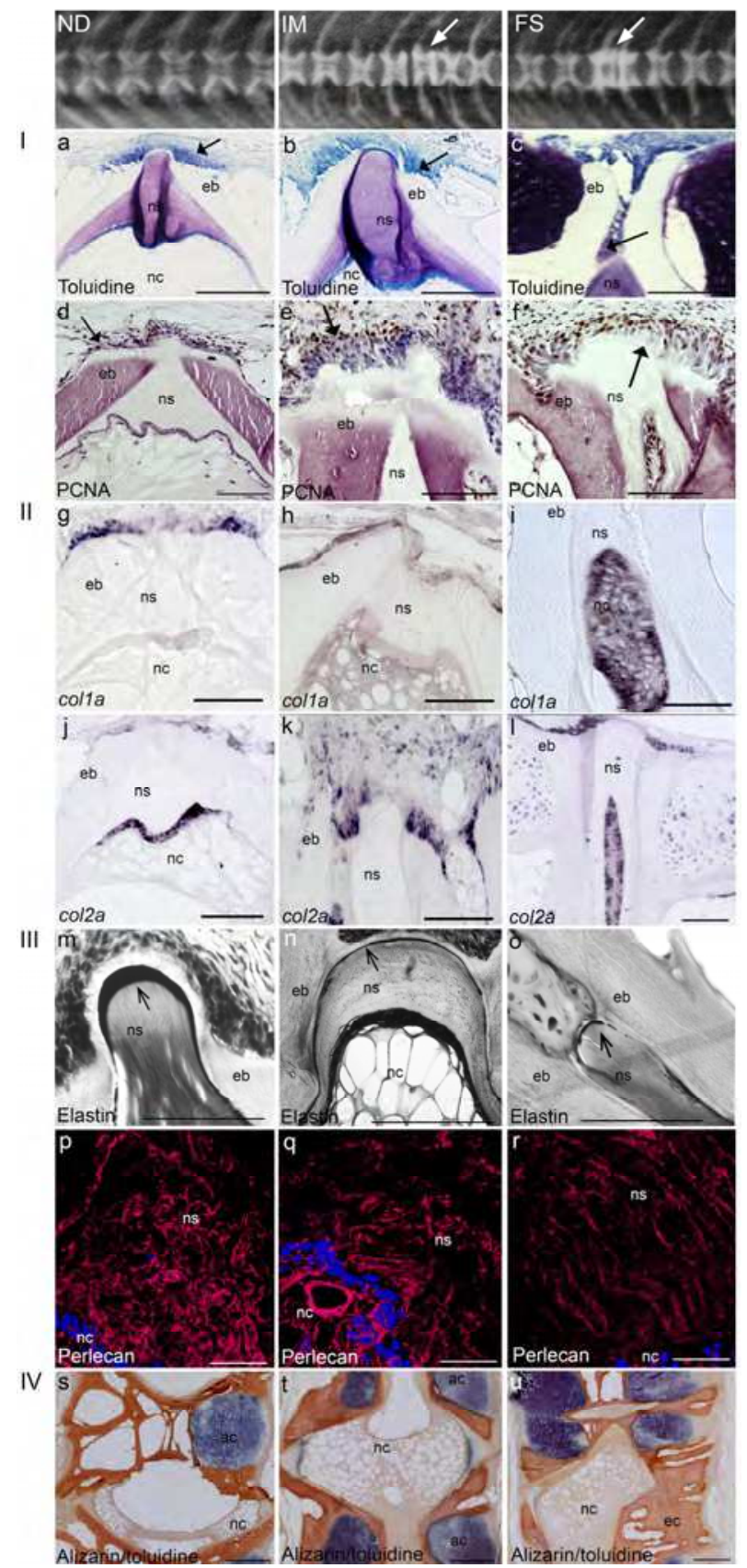

Fig. 10. Major findings during the development of vertebral fusions in Atlantic salmon. I Disorganization, II Metaplsatic shift, III Loss of notochordal sheath integrity, and IV Ectopic bone formation. See text for details. Scale bar = $100 \mu \mathrm{m}(\mathrm{a}-\mathrm{l}), 50 \mu \mathrm{m}(\mathrm{m}-\mathrm{r}), 200 \mu \mathrm{m}(\mathrm{s}-\mathrm{u})$. 


\section{III: Loss of notochordal sheath integrity}

The elastic membrane surrounding the notochord becomes fragmented and the notochordal sheath loose its integrity. Verhoeff's hematoxylin staining has visualized a thinner elastic membrane surrounding the notochordal sheath of developing vertebral fusions. In the most severe cases, the elastic membrane is fragmented. Furthermore, the highly folded structures in the notochordal sheath are lost during development of spinal fusions.

\section{IV: Ectopic bone formation}

Ectopic bone formation in the affected areas gives the vertebral bodies a squared morphology as the arch centra fuse and ossify. Ectopic mineralization of intervertebral regions and arch centra is formed, indicating that the proliferating and metaplastic cells not only differentiates towards osteoblast-like cells, but also complete the differentiation to cells that are capable of producing mineralized matrix. The intervertebral space narrows completely down and the notochord mineralizes.

The overall structural and molecular features of bone and cartilage development in vertebral fusions in Atlantic salmon have shown resemblance with similar pathological spinal conditions in mammals (Ytteborg et al., 2010c and d; Gorman et al., 2007; Witten et al., 2006). For example several mammalian studies have suggest that changes in the balance between cell death and cell proliferation is involved in bone and cartilage defects which may lead to malformations (Cockroft et al., 1978; Miura et al., 2004; Breen et al., 1999; Farquharson et al., 2000). Spinal fusions in Atlantic salmon are characterized by changes in ECM components and mineralization of the intervertebral regions (Ytteborg et al., 2010c; Witten et al., 2006). Similarly, intervertebral disc degeneration (IDD) in mammals involves breakdown of ECM components in the AF and calcification of the NP (Takaishi et al., 1997; Kanemoto et al., 1996; Antoniou et al., 1996). Fusion, compression and chondrogenic transformation of skeletal tissue have also been reported from lordosis and kyphosis in sea bass. Histological examinations of both lordosis and hyperdense vertebrae have further indicated cellular plasticity (like metaplastic shifts and trans-differentiation) and development of intermediate tissues as pathological events (Ytteborg et al., 2010c; Helland et al., 2006; Kranenbarg et al., 2006; Witten et al., 2006; Witten et al., 2005). It has previously been suggested that a metaplastic shift is involved in the development of spinal fusions, leading to the formation of chondroid bone which at later stages in the fusion process is replaced by bone. As previously discussed, chondrocytes associated with calcifying cartilage can acquire properties of osteoblasts (Cancedda et al., 1992) and are able to change their phenotype from a primarily cartilage synthesizing cell type to a bone synthesizing cell type (Lian et al., 1993). Co-transcription of chondrogenic and osteogenic marker genes in the arch centra and notochord supports the suggestion of an adaptation through metaplastic shifts during development of vertebral fusions, which may be induced to produce more robust cells that are able to withstand increased mechanical load. A pathway to bone formation through chondrocytes might be possible during development of vertebral fusions and fast growth, which could be similar to trans-chondroid ossification, as described by Yasui et al. (1997). Trans-differentiation and ectopic calcification has also been suggested as pathological pathways in lordotic sea bass where deformations stimulate ectopic bone formation in the intervertebral regions between two affected vertebral bodies and along the rims of the vertebral body endplates (Kranenbarg et al., 2006). Similarly, a shift in the mammalian IVD NP cell population coincides with spinal disorders like intervertebral disc degeneration and changes in the synthesis of matrix molecules differ 
with the degree of degeneration (Handa et al., 1997). The mammalian AF is further strengthened through cartilage formation upon elevated mechanical load (Lotz et al., 2002; Prescher et al., 1998). Moreover, breakdown of PG components, like Aggrecan and Perlecan, may lead to reduced hydrostatic pressure, invasion of nerves and blood vessels and loss of transportation of nutrients and waste products in degenerating IVD (Kauppila, 1995; Urban et al., 2003 and 2004; Melrose et al., 2002; Yasuma et al., 1993). Loss of Aggrecan resulting in tissue dehydration, reduces the ability of mammalian IVD to transmit and absorb compressive load (Kanemoto et al., 1996; Urban et al., 1985). Loss of Aggrecan and Perlecan has also been observed in the notochord of Atlantic salmon during development of vertebral fusions (Ytteborg et al. 2010d), which may possibly reduce the hydrostatic pressure and hence the transportation of nutrients and alteration of $\mathrm{pH}$ values. Another comparative pathological process to teleost vertebral fusions is the mammalian "Bamboo spine", describing a condition where vertebral bodies have fused and reshaped through ectopic bone formation (Bakay et al., 1970; Resnick et al., 1983). Witten et al.(2005) have described similar processes in Atlantic salmon. Fusing vertebral bodies may either stabilize as on large vertebral body or continue to develop through neighbouring vertebrae. What kind of cellular actions leading to a stabilized or aggravating fusion remains to be answered. However, it seems that different types of deformities have similar pathways of cellular pathological development, processes involving proliferation, metaplastic shifts, cellular instability and trans-differentiation.

\section{Conclusion}

During the last decade, fish have emerged as suitable animal models for studying bone and cartilage biology and have shown to be a suitable supplement to mammalian systems aiming to uncover the corresponding fundamental cellular and molecular mechanisms of action. In the light of metaplastic shifts during skeletal deformities in Atlantic salmon, a cell culture based system allowing for cellular differentiation and lineage determination studies have been developed. In this particular system, precursor cells are stimulated to myogenic, adipogenic and osteogenic differentiation, and opens up for studies where these cells can be manipulated upon different stimuli to undergo metaplastic shifts. Hence, functional studies can be performed to better characterize the pathology, define particular requirements and minimize the occurrence of bone disorders. Advanced methods and defined molecular markers should enable us to detect the risk of developing deformities early in ontogeny. Similar diagnostics and medications as those existing in the human medicine will not be applicable for farmed animals. However, treatments and diets have shown to be well suited also for teleosts. Exercise and addition of minerals in the feed have already shown positive effects in regards of bone quality and should be further addressed in future research.

\section{Acknowledgments}

The authors would like to thank Johanne Halvorsen (www.forestry.no) for help with graphic illustrations.

\section{References}

Adams DS, Keller R, Koehl MAR (1990) The Mechanics of Notochord Elongation, Straightening and Stiffening in the Embryo of Xenopus-Laevis. Development, 110: 115-130. 
Anderson HC, Cecil R, Sajdera SW (1975) Calcification of Rachitic Rat Cartilage Invitro by Extracellular Matrix Vesicles. American Journal of Pathology, 79: 237-254.

Anderson HC, Garimella R, Tague SE (2005) The role of matrix vesicles in growth plate development and biomineralization. Frontiers in Bioscience, 10: 822-837.

Anderson HC (1996) Molecular-Biology of Matrix Vesicles. Clinical Orthopaedics and Related Research, 266-280.

Antoniou J, Steffen T, Nelson F, Winterbottom N, Hollander AP, Poole RA, Aebi M, Alini M (1996) The human lumbar intervertebral disc: evidence for changes in the biosynthesis and denaturation of the extracellular matrix with growth, maturation, ageing, and degeneration. Journal of Clinical Investigation, 98: 996-1003.

Arendt JD (2000) Allocation of cells to proliferation vs. differentiation and its consequences for growth and development. Journal of Experimental Zoology, 288: 219-234.

Arnold MA, Kim Y, Czubryt MP, Phan D, McAnally J, Qi X (2007) MEF2C transcription factor controls chondrocyte hypertrophy and bone development. Developmental Cell, 12: 377-389.

Arratia G, Schultze HP, Casciotta J (1998) Vertebral column and associated elements in dipnoans and comparison with other fishes: Development and homology. Journal of Morphology 2001, 250: 101-172.

Aubin JE (1998) Bone stem cells. Journal of Cellular Biochemistry, 73-82.

Aviezer D, Hecht D, Safran M, Eisinger M, David G, Yayon A (1994) Perlecan, basal lamina proteoglycan, promotes basic fibroblast growth factor-receptor binding, mitogenesis, and angiogenesis. Cell, Volume 79:6, 1005-1013.

Baeverfjord G, Åsgård T, Rye M, Storset A (1998) High temperatures during egg incubation may induce malformations in Atlantic salmon (Salmo salar L.). Aguaculture and water, EAS special publication no 26, pp. 24-25.

Baeverfjord G, Åsgård T, Shearer KD (1998) Development and detection of phosphorus deficiency in Atlantic salmon (Salmo salar). Aquacquaculture Nutrition, 4:1-11.

Baeverfjord G. (1999) Deformities induced by temperature stress in farmed Atlantic salmon and Rainbow trout. Report to the Norwegian Research Council of Norway, pp. 19.

Bakay L, Cares HL, Smith RJ (1970) Ossification in Region of Posterior Longitudinal Ligament As A Cause of Cervical Myelopathy. Journal of Neurology Neurosurgery and Psychiatry, 33: 263-371.

Balcerzak M, Hamade E, Zhang L, Pikula S, Azzar G, Radisson J (2003) The roles of annexins and alkaline phosphatase in mineralization process. Acta Biochimica Polonica, 50: 1019-1038.

Bell DM, Leung KKH, Wheatley SC, Ng LJ, Zhou S, Ling KW (1997) SOX9 directly regulates the type-II collagen gene. Nature Genetics 1997, 16: 174-178.

Bengtsson BE (1979) Biological Variables, Especially Skeletal Deformities in Fish, for Monitoring Marine Pollution. Philosophical Transactions of the Royal Society of London Series B-Biological Sciences, 286: 457-464.

Berg A, Rodseth OM, Tangeras A, Hansen T (2006) Time of vaccination influences development of adhesions, growth and spinal deformities in Atlantic salmon (Salmo salar). Diseases of Aquatic Organisms, 69: 239-248. 
Berntssen MHG, Waagbo R, Toften H, Lundebye AK (2003) Effects of dietary cadmium on calcium homeostasis, Ca mobilization and bone deformities in Atlantic salmon (Salmo salar L.) parr. Aquaculture Nutrition, 9: 175-183.

Blavier L, Delaisse JM (1995) Matrix Metalloproteinase Activity Is Obligatory for the Recruitment of Osteoclasts to Future Bone-Resorption Sites. Journal of Bone and Mineral Research, 10: S224.

Bolander ME, Young MF, Fisher LW, Yamada Y, Termine JD (1998) Osteonectin cDNA Sequence Reveals Potential Binding Regions for Calcium and Hydroxyapatite and Shows Homologies with Both A Basement-Membrane Protein (Sparc) and A Serine Proteinase-Inhibitor (Ovomucoid). Proceedings of the National Academy of Sciences of the United States of America, 85: 2919-2923.

Boyle WJ, Simonet WS, Lacey DL (2003) Osteoclast differentiation and activation. Nature, 423: 337-342.

Braga D, Laizé V, Tiago DM, Cancela ML (2006) Enhanced DNA transfer into fish bone cells using polyethylenimine. Mol Biotechnol 34:51-54.

Brand-Saberi B, Christ B (2000) Evolution and development of distinct cell lineages derived from somites. Current Topics in Developmental Biology, 48, 48: 1-42.

Breen JG, Claggett TW, Kimmel GL, Kimmel CA (1999) Heat shock during rat embryo development in vitro results in decreased mitosis and abundant cell death. Reproductive Toxicology, 13: 31-39.

Bruger, C, Ridler, N (2004) Global aquaculture outlook in the next decades: an analysis of national aquaculture production forecasts to 2030. Fisheries Circular No. 1001 (FAO ed.), pp. 47. FAO, Rome

Cahu C, Infante JZ, Takeuchi T (2003) Nutritional components affecting skeletal development in fish larvae. Aquaculture, 227: 245-258.

Cancedda FD, Gentili C, Manduca P, Cancedda R (1992) Hypertrophic Chondrocytes Undergo Further Differentiation in Culture. Journal of Cell Biology 1992, 117: 427435.

Cleaver O, Krieg PA (2001) Notochord patterning of the endoderm. Developmental Biology 234: 1-12.

Cockroft DL, New DAT (1978) Abnormalities Induced in Cultured Rat Embryos by Hyperthermia. Teratology, 17: 277-283.

Collin-Osdoby P (2004) Regulation of vascular calcification by osteoclast regulatory factors RANKL and osteoprotegerin. Circulation Research 95: 1046-1057.

Conceição N, Laizé V, Simões B, Pombinho AR, Cancela ML (2008) Retinoic acid is a negative regulator of matrix Gla protein gene expression in teleost fish Sparus aurata. Biochim. Biophys. Acta 1779, 28-39.

Cowles EA, Derome ME, Pastizzo G, Brailey LL, Gronowicz GA (1998) Mineralization and the expression of matrix proteins during in vivo bone development. Calcified Tissue International, 62: 74-82.

Delaisse JM, Andersen TL, Engsig MT, Henriksen K, Troen T, Blavier L (2003) Matrix metalloproteinases (MMP) and cathepsin $\mathrm{K}$ contribute differently to osteoclastic activities. Microscopy Research and Technique 61: 504-513. 
DeLaurier A, Eames BF, Blanco-Sánchez B, Peng G, He X, Swartz ME, Ullmann B, Westerfield M, Kimmel CB (2010) Zebrafish sp7:EGFP: a transgenic for studying otic vesicle formation, skeletogenesis, and bone regeneration. Genesis. 48(8):505-11.

Denstadli V, Witten PE, Hjelde K, Storebakken T, Skrede A (2006) Hyper dense vertebrae and mineral content in Atlantic salmon (Salmo salar L.) fed diets with graded levels of phytic acid. Aquaculture 2006, 261: 603-614.

Divanach P, Papandroulakis N, Anastasiadis P, Koumoundouros G, Kentouri M (1007) Effect of water currents on the development of skeletal deformities in sea bass (Dicentrarchus labrax L.) with functional swimbladder during postlarval and nursery phase. Aquaculture, 156: 145-155.

Domowicz M, Li H, Hennig A, Henry J, Vertel BM, Schwartz NB (1995) The Biochemically and Immunologically Distinct Cspg of Notochord Is A Product of the Aggrecan Gene. Developmental Biology 1995, 171: 655-664.

Engsig MT, Chen QJ, Vu TH, Pedersen AC, Therkidsen B, Lund LR (2000) Matrix metalloproteinase 9 and vascular endothelial growth factor are essential for osteoclast recruitment into developing long bones. Journal of Cell Biology 151: 879889.

Erlebacher A, Filvaroff EH, Gitelman SE, Derynck R (1995) Toward A Molecular Understanding of Skeletal Development. Cell 80: 371-378.

Farquharson C, Jefferies D. (2000) Chondrocytes and longitudinal bone growth: The development of tibial dyschondroplasia. Poultry Science 79: 994-1004.

Fisher S, Jagadeeswaran P, Halpern ME (2003) Radiographic analysis of zebrafish skeletal defects. Dev. Biol. 264, 64-76.

Fjelldal G, Hansen TJ, Berg AE (2007) A radiological study on the development of vertebral deformities in cultured Atlantic salmon (Salmo salar L.). Aquaculture, 273: 721-728.

Fjelldal PG, Hansen T, Breck O, Sandvik R, Waagbo R, Berg A (2009)Supplementation of dietary minerals during the early seawater phase increase vertebral strength and reduce the prevalence of vertebral deformities in fast-growing under-yearling Atlantic salmon (Salmo salar L.) smolt. Aquaculture Nutrition, 15: 366-378.

Fjelldal PG, Lock EJ, Grotmol S, Totland GK, Nordgarden U, Flik G (2006)Impact of smolt production strategy on vertebral growth and mineralisation during smoltification and the early seawater phase in Atlantic salmon (Salmo salar). Aquaculture, 261: 715728.

Fjelldal PG, Nordgarden U, Berg A, Grotmol S, Totland GK, Wargelius A (2005) Vertebrae of the trunk and tail display different growth rates in response to photoperiod in Atlantic salmon, Salmo salar L., post-smolts. Aquaculture, 250: 516-524.

Flanagan JA, Power DM, Bendell LA, Guerreiro PM, Fuentes J, Clark MS, Canario AVM, Danks JA, Brown BL, Ingleton PM (2000). Cloning of the cDNA for Sea Bream (Sparus aurata) Parathyroid Hormone-Related Protein. General and Comparative Endocrinology 118:3, 373-382.

Fleming A, Keynes R, Tannahill D (2004) A central role for the notochord in vertebral patterning. Development, 131: 873-880.

Fonseca VG, Laizé V, Valente MS, Cancela ML (2007) Identification of an osteopontin-like protein in fish associated with mineral formation. FEBS J. 274, 4428-4439. 
Freemont AJ (2009) The cellular pathobiology of the degenerate intervertebral disc and discogenic back pain. Rheumatology 48: 5-10.

Furie B, Furie BC (1991) Molecular-Basis of Gamma-Carboxylation, Role of the Propeptide in the Vit K-Dependent Proteins. Annals of the New York Academy of Sciences 614: 1-10.

Gjerde B, Pante MJR, Baeverfjord G (2005) Genetic variation for a vertebral deformity in Atlantic salmon (Salmo salar). Aquaculture 244: 77-87.

Glickman NS, Kimmel CB, Jones MA, Adams RJ (2003) Shaping the zebrafish notochord. Development 130: 873-887.

Gorman KF, Breden F (2007) Teleosts as models for human vertebral stability and deformity. Comp. Biochem. Physiol. C Toxicol. Pharmacol. 145, 28- 38.

Grotmol S, Kryvi H, Keynes R, Krossoy C, Nordvik K, Totland GK (2006) Stepwise enforcement of the notochord and its intersection with the myoseptum: an evolutionary path leading to development of the vertebra? Journal of Anatomy 209: 339-357.

Grotmol S, Kryvi H, Nordvik K, Totland GK (2003) Notochord segmentation may lay down the pathway for the development of the vertebral bodies in the Atlantic salmon. Anatomical Embryology, 207: 263-272.

Grotmol S, Nordvik K, Kryvi H, Totland GK (2005) A segmental pattern of alkaline phosphatase activity within the notochord coincides with the initial formation of the vertebral bodies. Journal of Anatomy 206: 427-436.

Hammond CL, Simbi BH, Stickland NC (2007) In ovo temperature manipulation influences embryonic motility and growth of limb tissues in the chick (Gallus gallus). Journal of Experimental Biology, 210: 2667-2675.

Handa T, Ishihara H, Ohshima H, Osada R, Tsuji H, Obata K (1997) Effects of hydrostatic pressure on matrix synthesis and matrix metalloproteinase production in the human lumbar intervertebral disc. Spine 22: 1085-1091.

Hayes AJ, Benjamin M, Ralphs JR (2001) Extracellular matrix in development of the intervertebral disc. Matrix Biology, 20: 107-121.

Haynes CM, Titus EA, Cooper AA (2004) Degradation of misfolded proteins prevents ERderived oxidative stress and cell death. Molecular Cell, 15: 767-776.

Helland S, Denstadli V, Witten PE, Hjelde K, Storebakken T, Skrede A (2006) Hyper dense vertebrae and mineral content in Atlantic salmon (Salmo salar L.) fed diets with graded levels of phytic acid. Aquaculture, 261: 603-614.

Hernandez CJ, Beaupre GS, Carter DR (2000) A model of mechanobiologic and metabolic influences on bone adaptation. Journal of Rehabilitation Research and Development, 37: 235-244.

Hoffmann HM, Beumer TL, Rahman S, Mccabe LR, Banerjee C, Aslam F (1996) Bone tissuespecific transcription of the osteocalcin gene: Role of an activator osteoblast-specific complex and suppressor hox proteins that bind the OC box. Journal of Cellular Biochemistry, 61: 310-324.

Hogan BLM, Cooper AR, Kurkinen M (1980) Incorporation Into Reicherts Membrane of Laminin-Like Extracellular Proteins Synthesized by Parietal Endoderm Cells of the Mouse Embryo. Developmental Biology, 80: 289-300. 
Hunter CJ, Matyas JR, Duncan NA(2003) The three-dimensional architecture of the notochordal nucleus pulposus: novel observations on cell structures in the canine intervertebral disc. Journal of Anatomy, 202: 279-291.

Hunziker EB (1994) Mechanism of Longitudinal Bone-Growth and Its Regulation by Growth-Plate Chondrocytes. Microscopy Research and Technique, 28: 505-519.

Huysseune A, Sire JY (1990) Ultrastructural Observations on Chondroid Bone in the Teleost Fish Hemichromis bimaculatus. Tissue \& Cell, 22: 371-383.

Huysseune A, Verraes W (1986) Chondroid Bone on the Upper Pharyngeal Jaws and Neurocranial Base in the Adult Fish Astatotilapia elegans. American Journal of Anatomy, 177: 527-535.

Ida-Yonemochi H, Ohshiro K, Swelam W, Metwaly H, Saku T. (2005) Perlecan, a basement membrane-type heparin sulfate proteoglycan, in the enamel organ: its intraepithelial localization in the stellate reticulum. J Histochem Cytochem 53:763772.

Ikeda T, Nomura S, Yamaguchi A, Suda T, Yoshiki S (1992) In situ Hybridization of BoneMatrix Proteins in Undecalcified Adult-Rat Bone Sections. Journal of Histochemistry \& Cytochemistry, 40: 1079-1088.

Inada M, Yasui T, Nomura S, Miyake S, Deguchi K, Himeno M (1999) Maturational disturbance of chondrocytes in Cbfa1-deficient mice. Developmental Dynamics, 214 : 279-290.

Ishizeki K, Takigawa M, Harada Y, Suzuki F, Nawa T (1996) Meckel's cartilage chondrocytes in organ culture synthesize bone-type proteins accompanying osteocytic phenotype expression. Anatomy and Embryology, 193: 61-71.

Iyama K, Ninomiya Y, Olsen BR, Linsenmayer TF, Trelstad RL, Hayashi M (1991) Spatiotemporal Pattern of Type-X Collagen Gene-Expression and Collagen Deposition in Embryonic Chick Vertebrae Undergoing Endochondral Ossification. Anatomical Record, 229: 462-472.

Julian RJ (2005) Production and growth related disorders and other metabolic diseases of poultry - A review. Veterinary Journal, 169: 350-369.

Julian RJ (1998) Rapid growth problems: Ascites and skeletal deformities in broilers. Poultry Science, 77: 1773-1780.

Jutfelt F, Olsen RE, Björnsson BT, Sundell K (2007). Parr-smolt transformation and dietary vegetable lipids affect intestinal nutrient uptake, barrier function and plasma cortisol levels in Atlantic salmon. Aquaculture 273; 298-311.

Kacem A, Meunier FJ, Bagliniere JL (1998) A quantitative study of morphological and histological changes in the skeleton of Salmo salar during its anadromous migration. Journal of Fish Biology, 53: 1096-1109.

Kanemoto M, Hukuda S, Komiya Y, Katsuura A, Nishioka J (1996) Immunohistochemical study of matrix metalloproteinase- 3 and tissue inhibitor of metalloproteinase- 1 in human intervertebral discs. Spine 21:1-8.

Karp SJ, Schipani E, St-Jacques B, Hunzelman J, Kronenberg H, McMahon AP (2000) Indian hedgehog coordinates endochondral bone growth and morphogenesis via Parathyroid Hormone related-Protein-dependent and -independent pathways. Development, 127: 543-548. 
Karsenty G, Ducy P, Starbuck M, Priemel M, Shen J, Geoffroy V (1999) Cbfa1 as a regulator of osteoblast differentiation and function. Bone, 25: 107-108.

Karsenty G, Kronenberg HM, Settembre C. (2009). Genetic Control of Bone Formation. Annual Review of Cell and Developmental Biology 25: 629-648.

Kauppila LI (1995). Ingrowth of blood vessels in disc degeneration. Angiographic and histological studies of cadaveric spines. J Bone Joint Surg Am. 77(1):26-31.

Kieswetter K, Schwartz Z, Alderete M, Dean DD, Boyan BD (1997) Platelet derived growth factor stimulates chondrocyte proliferation but prevents endochondral maturation. Endocrine, 6: 257-264.

Kikuta H, Laplante M, Navratilova P, Komisarczuk AZ, Engstrom PG, Fredman D (2007) Genomic regulatory blocks encompass multiple neighboring genes and maintain conserved synteny in vertebrates. Genome Research, 17: 545-555.

Kim IS, Otto F, Zabel B, Mundlos S (1999) Regulation of chondrocyte differentiation by Cbfa1. Mechanisms of Development, 80: 159-170.

Kimmel CB, DeLaurier A, Ullmann B, Dowd J, McFadden M (2010). Modes of developmental outgrowth and shaping of a craniofacial bone in zebrafish. PLoS One. 5;5(3):e9475.

Kirsch T, Nah HD, Shapiro IM, Pacifici M (1997) Regulated production of mineralizationcompetent matrix vesicles in hypertrophic chondrocytes. Journal of Cell Biology, 137: $1149-1160$.

Kirsch T (2005) Annexins - Their role in cartilage mineralization. Frontiers in Bioscience, 10: 576-581.

Koehl MAR, Quillin KJ, Pell CA (2000) Mechanical design of fiber-wound hydraulic skeletons: The stiffening and straightening of embryonic notochords. American Zoologist, 40: 28-41.

Koumoundouros G, Divanach P, Kentouri M (2001) The effect of rearing conditions on development of saddleback syndrome and caudal fin deformities in Dentex dentex (L.). Aquaculture, 200: 285-304.

Kranenbarg S, Schipper H, van Leeuwen J (2006) Local biophysical stimuli and chondroid bone in lordotic vertebrae of the sea bass. Comparative Biochemistry and Physiology AMolecular \& Integrative Physiology, 143: S95.

Kranenbarg S, van Cleynenbreugel T, Schipper H, van Leeuwen J (2005) Adaptive bone formation in acellular vertebrae of sea bass (Dicentrarchus labrax L.). Journal of Experimental Biology, 208: 3493-3502.

Krossøy C, Ørnsrud R, Wargelius A (2009) Differential gene expression of bgp and mgp in trabecular and compact bone of Atlantic salmon (Salmo salar L.) Journal of Anatomy 215:6, 663-672.

Laerm J (1976) Development, Function, and Design of Amphicoelous Vertebrae in Teleost Fishes. Zoological Journal of the Linnean Society, 58: 237-254.

Lall SP, Lewis-McCrea LM (2007) Role of nutrients in skeletal metabolism and pathology in fish - An overview. Aquaculture, 267: 3-19.

Leterrier C, Nys Y (1992) Clinical and Anatomical Differences in Varus and Valgus Deformities of Chick Limbs Suggest Different Etiopathogenesis. Avian Pathology, 21: 429-442. 
Lian JB, Mckee MD, Todd AM, Gerstenfeld LC (1993) Induction of Bone-Related Proteins, Osteocalcin and Osteopontin, and Their Matrix Ultrastructural-Localization with Development of Chondrocyte Hypertrophy Invitro. Journal of Cellular Biochemistry, 52: 206-219.

Linsenma TF, Trelstad RL, Gross J (1973) Collagen of Chick Embryonic Notochord. Biochemical and Biophysical Research Communications, 53: 39-45.

Lock EJ, Ornsrud R, Aksnes L, Spanings FAT, Waagbo R, Flik G (2007) The vitamin D receptor and its ligand 1 alpha,25-dihydroxyvitamin D-3 in Atlantic salmon (Salmo salar). Journal of Endocrinology, 193: 459-471.

Lotz JC, Hsieh AH, Walsh AL, Palmer EI, Chin JR (2002) Mechanobiology of the intervertebral disc. Biochemical Society Transactions, 30: 853-858.

Mackie EJ, Ahmed YA, Tatarczuch L, Chen KS, Mirams M (2008) Endochondral ossification: How cartilage is converted into bone in the developing skeleton. International Journal of Biochemistry \& Cell Biology, 40: 46-62.

Madsen L, Arnbjerg J, Dalsgaard I (2000) Spinal deformities in triploid all-female rainbow trout. Bulletin of the European Association of Fish Pathologists, 20: 206-208.

Melrose J, Roberts S, Smith S, Menage J, Ghosh P (2002) Increased nerve and blood vessel ingrowth associated with proteoglycan depletion in an ovine anular lesion model of experimental disc degeneration. Spine 27:1278-1285.

Miura M, Chen XD, Allen MR, Bi YM, Gronthos S, Seo BM (2004): A crucial role of caspase-3 in osteogenic differentiation of bone marrow stromal stem cells. Journal of Clinical Investigation, 114: 1704-1713.

Morita H, Yoshimura A, Inui K, Lodeura T, Watanabe H, Wang L (2005) Heparan sulfate of perlecan is involved in glomerular filtration. Journal of the American Society of Nephrology, 16: 1703-1710.

Motyckova G, Weilbaecher KN, Horstmann M, Rieman DJ, Fisher DZ, Fisher DE (2001) Linking osteopetrosis end pycnodysostosis: Regulation of cathepsin $\mathrm{K}$ expression by the microphthalmia transcription factor family. Proceedings of the National Academy of Sciences of the United States of America, 98: 5798-5803.

Nakashima K, de Crombrugghe B (2003) Transcriptional mechanisms in osteoblast differentiation and bone formation. Trends Genet, 19: 458-466.

Nakashima K, Zhou X, Kunkel G, Zhang ZP, Deng JM, Behringer RR (2002) The novel zinc finger-containing transcription factor Osterix is required for osteoblast differentiation and bone formation. Cell, 108: 17-29.

Nissen RM, Amsterdam A, Hopkins N (2006) A zebrafish screen for craniofacial mutants identifies $w d r 68$ as a highly conserved gene required for endothelin-1 expression. BMC Dev. Biol. 6, 28.

Nordvik K, Kryvi H, Totland GK, Grotmol S (2005) The salmon vertebral body develops through mineralization of two preformed tissues that are encompassed by two layers of bone. Journal of Anatomy, 206: 103-114.

Oegema TR (2002) The role of disc cell heterogeneity in determining disc biochemistry: a speculation. Biochemical Society Transactions, 30: 839-844.

Ohashi N, Robling AG, Burr DB, Turner CH (2002) The effects of dynamic axial loading on the rat growth plate. Journal of Bone and Mineral Research, 17: 284-292. 
Ortega N, Behonick D, Stickens D, Werb Z (2003) How proteases regulate bone morphogenesis. Tissue Remodeling, 995: 109-116.

Otto F, Thornell AP, Crompton T, Denzel A, Gilmour KC, Rosewell IR (1997) Cbfa1, a candidate gene for cleidocranial dysplasia syndrome, is essential for osteoblast differentiation and bone development. Cell, 89: 765-771.

Parsons MJ, Pollard SM, Saude L, Feldman B, Coutinho P, Hirst EMA (2002) Zebrafish mutants identify an essential role for laminins in notochord formation. Development, 129: 3137-3146.

Patel JJ, Orriss IR, Key ML, Taylor SEB, Karnik K, Arnett R (2009) Hypothermia stimulates osteoclastogenesis but inhibits osteoblast differentiation and bone formation. Bone 2009, 44: S305.

Pedersen ME, Takle H, Ytteborg E, Veiseth E, Enersen G, Færgestad E, Bæverfjord G, Hannesson KO (2010) Matrilin-1 in the vertebral column of Atlantic Salmon (Salmo Salar L) with skeletal deformities. Fish Phys Biochem PMID 21452016.

Pinto JP, Ohresser MCP, Cancela ML (2001) Cloning of the bone Gla protein gene from the teleost fish Sparus aurata. Evidence for overall conservation in gene organization and bone-specific expression from fish to man. Gene, 270: 77-91.

Pratap J, Javed A, Languino LR, van Wijnen AJ, Stein JL, Stein GS (2005) The Runx2 osteogenic transcription factor regulates matrix metalloproteinase 9 in bone metastatic cancer cells and controls cell invasion. Mol Cell Biol, 25: 8581-8591.

Prescher A (1998) Anatomy and pathology of the aging spine. European Journal of Radiology 1998, 27: 181-195.

Preziosi R, Gridelli S, Borghetti P, Diana A, Parmeggiani A, Fioravanti ML (2006) Spinal deformity in a sandtiger shark, Carcharias taurus Rafinesque: a clinical-pathological study. Journal of Fish Diseases, 29: 49-60.

Rafael MS, Laizé V, Cancela ML (2006) Identification of Sparus aurata bone morphogenetic protein 2: molecular cloning, gene expression and in silico analysis of protein conserved features in vertebrates. Bone 39, 1373-1381.

Rawlinson SCF, Murray DH, Mosley JR, Wright CDP, Bredl JC, Saxon LK (2009) Genetic selection for fast growth generates bone architecture characterised by enhanced periosteal expansion and limited consolidation of the cortices but a diminution in the early responses to mechanical loading. Bone, 45: 357-366.

Reiland S (1978) Effect of Decreased Growth-Rate on Frequency and Severity of Osteochondrosis in Pigs. Acta Radiologica-Diagnosis, 107-122.

Renn J, Winkler C, Schartl M, Fischer R, Goerlich R (2006) Zebralish and medaka as models for bone research including implications regarding space-related issues. Protoplasma, 229: 209-214.

Resnick D (1983) Case Report-240 - Fibrodysplasia Ossificans Progessiva (Fop) Radiological and Gross Pathological Abnormalities in A Macerated Cadaver. Skeletal Radiology 10: 131-136.

Robling AG, Duijvelaar KM, Geevers JV, Ohashi N, Turner CH (2001) Modulation of appositional and longitudinal bone growth in the rat ulna by applied static and dynamic force. Bone, 29: 105-113. 
Roy PK, Witten PE, Hall BK, Lall SP (2002) Effects of dietary phosphorus on bone growth and mineralisation of vertebrae in haddock (Melanogrammus aeglefinus L.). Fish Physiology and Biochemistry, 27: 35-48.

Sandell LJ (1994) In-Situ Expression of Collagen and Proteoglycan Genes in Notochord and During Skeletal Development and Growth. Microscopy Research and Technique, 28: 470-482.

Shafizadeh E, Paw BH (2004) Zebrafish as a model of human hematologic disorders. Current Opinion in Hematology, 11: 255-261.

Silverstone AM, Hammell L (2002) Spinal deformities in farmed Atlantic salmon. Canadian Veterinary Journal-Revue Veterinaire Canadienne, 43: 782-784.

Sivan SS, Tsitron E, Wachtel E, Roughley PJ, Sakkee N, Ham F van der, DeGroot J, Roberts S, Maroudas A (2006) Aggrecan turnover in human intervertebral disc as determined by the racemization of aspartic acid. J Biol Chem 281:13009-13014.

Smith SM, Whitelock JM, Iozzo RV, Little CB, Melrose J (2009) Topographical variation in the distributions of versican, aggrecan and perlecan in the foetal human spine reflects their diverse functional roles in spinal development. Histochemistry and Cell Biology, 132: 491-503.

Spinella-Jaegle S, Rawadi G, Kawai S, Gallea S, Faucheu C, Mollat P, Courtois B, Bergaud B, Ramez V, Blanchet AM, Adelmant G, Baron R, Roman-Roman S (2001) Sonic hedgehog increases the commitment of pluripotent mesenchymal cells into the osteoblastic lineage and abolishes adipocytic differentiation. Journal of cell science 114(Pt 11):2085-94.

Sugiura SH, Hardy RW, Roberts RJ (2004) The pathology of phosphorus deficiency in fish a review, Journal of fish diseases, 27:5, 255-265.

Sullivan M, Hammond G, Roberts RJ, Manchester NJ (2007) Spinal deformation in commercially cultured Atlantic salmon, Salmo salar L.: a clinical and radiological study. Journal of Fish Diseases, 30: 745-752.

Takaishi H, Nemoto O, Shiota M, Kikuchi T, Yamada H, Yamagishi M, Yabe Y (1997) TypeII collagen gene expression is transiently upregulated in experimentally induced degeneration of rabbit intervertebral disc Jourrial of Orthopaedic Research 15:4 528538.

Termine JD, Kleinman HK, Whitson SW, Conn KM, Mcgarvey ML, Martin GR (1981) Osteonectin, A Bone-Specific Protein Linking Mineral to Collagen. Cell, 26: 99105.

Timpl R (1996) Macromolecular organization of basement membranes. Current Opinion in Cell Biology, 8: 618-624.

Tsang KY, Chan D, Cheslett D, Chan WCW, So CL, Melhado IG (2007) Surviving endoplasmic reticulum stress is coupled to altered chondrocyte differentiation and function. PLOS Biology, 5: 568-585.

Urban JPG, Mcmullin JF (1985) Swelling Pressure of the Intervertebral Disk - Influence of Proteoglycan and Collagen Contents. Biorheology 22:145-157.

Urban JPG, Roberts S (2003) Degeneration of the intervertebral disc. Arthritis Research \& Therapy 5:120-130

Urban JPG, Smith S, Fairbank JCT (2004) Nutrition of the intervertebral disc. Spine 29:27002709. 
Vagsholm I, Djupvik HO (1998) Risk factors for spinal deformities in Atlantic salmon, Salmo salar L. Journal of Fish Diseases, 21: 47-53.

Vandenavyle MJ, Garvick SJ, Blazer VS, Hamilton SJ, Brumbaugh WG (1989) Skeletal Deformities in Smallmouth Bass, Micropterus-Dolomieui, from Southern Appalachian Reservoirs. Archives of Environmental Contamination and Toxicology, 18: 688-696.

Wagner WM, Hartley MP, Duncan NM, Barrows MG (2005) Spinal spondylosis and acute intervertebral disc prolapse in a European brown bear (Ursus arctos arctos). Journal of the South African Veterinary Association, 76: 120-122.

Walmsley R (1953) The development and growth of the intervertebral disc. Edinburgh Medical.Journal 60, 341-364.

Wargelius A, Fjelldal PG, Hansen T (2005) Heat shock during early somitogenesis induces caudal vertebral column defects in Atlantic salmon (Salmo salar). Dev Genes Evol, 215: 350-357.

Wargelius A, Fjelldal PG, Nordgarden U, Hansen T (2009) Continuous light affects mineralization and delays osteoid incorporation in vertebral bone of Atlantic salmon (Salmo salar L.). Journal of Experimental Biology, 212: 656-661.

Wiktorjedrzejczak W, Bartocci A, Ferrante AW, Ahmedansari A, Sell KW, Pollard JW (1990) Total Absence of Colony-Stimulating Factor 1 in the Macrophage-Deficient Osteopetrotic (Op Op) Mouse. Proceedings of the National Academy of Sciences of the United States of America, 87: 4828-4832.

Wise SB, Stock DW (2006) Conservation and divergence of Bmp2a, Bmp2b, and Bmp4 expression patterns within and between dentitions of teleost fishes. Evolution $\mathcal{E}$ Development, 8: 511-523.

Witten PE, Gil-Martens L, Hall BK, Huysseune A, Obach A (2005) Compressed vertebrae in Atlantic salmon Salmo salar: evidence for metaplastic chondrogenesis as a skeletogenic response late in ontogeny. Diseases of Aquatic Organisms, 64: 237-246.

Witten PE, Gil-Martens L, Huysseune A, Takle H, Hjelde K (2009) Towards a classification and an understanding of developmental relationships of vertebral body malformations in Atlantic salmon (Salmo salar L.). Aquaculture, 295: 6-14.

Witten PE, Hall BK (2002) Differentiation and growth of kype skeletal tissues in anadromous male Atlantic Salmon (Salmo salar). International Journal of Developmental Biology, 46: 719-730.

Witten PE, Huysseune A (2009) A comparative view on mechanisms and functions of skeletal remodelling in teleost fish, with special emphasis on osteoclasts and their function. Biological Reviews, 84: 315-346.

Witten PE, Obach A, Huysseune A, Baeverfjord G (2006) Vertebrae fusion in Atlantic salmon (Salmo salar): Development, aggravation and pathways of containment. Aquaculture, 258: 164-172.

Wu LNY, Genge BR, Wuthier RE (1991) Association Between Proteoglycans and Matrix Vesicles in the Extracellular-Matrix of Growth Plate Cartilage. Journal of Biological.

Yasui N, Sato M, Ochi T, Kimura T, Kawahata H, Kitamura Y (1997) Three modes of ossification during distraction osteogenesis in the rat. Journal of Bone and Joint Surgery-British Volume, 79B: 824-830. 
Yasuma T, Arai K, Yamauchi Y (1993) The Histology of Lumbar Intervertebral Disc Herniation - the Significance of Small Blood-Vessels in the Extruded Tissue. Spine 18:1761-1765.

Yoshida H, Hayashi SI, Kunisada T, Ogawa M, Nishikawa S, Okamura H (1990) The Murine Mutation Osteopetrosis Is in the Coding Region of the Macrophage Colony Stimulating Factor Gene. Nature, 345: 442-444.

Ytteborg E, Baeverfjord G, Hjelde K, Torgersen J, Takle H (2010b) Molecular pathology of vertebral deformities in hyperthermic Atlantic salmon (Salmo salar). BMC Physiology, 10:12.

Ytteborg E, Torgersen J, Baeverfjord G, Takle H (2010c) Morphological and molecular characterization of developing vertebral fusions using a teleost model. BMC Physiology, 10:13.

Ytteborg E, Torgersen J, Pedersen M, Baeverfjord G, Hannesson K, Takle H (2010d) Remodeling of the notochord during development of vertebral fusions in Atlantic salmon (Salmo salar). Cell and tissue research.

Ytteborg E, Vegusdal A, Witten PE, Berge G, Takle H, Østbye TK, Ruyter B (2010a) Atlantic salmon precursor cells from white muscle differentiate into osteoblasts in vitro: Polyunsaturated fatty acids and temperature influence gene expression and PGE2 production. Biochemica et Biophysica Acta Molecular Cell Research, 1801; 127-137. 


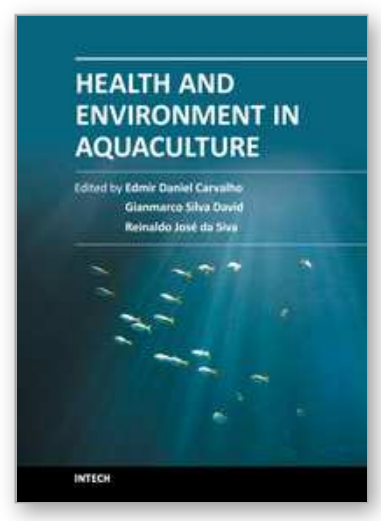

\author{
Health and Environment in Aquaculture \\ Edited by Dr. Edmir Carvalho
}

ISBN 978-953-51-0497-1

Hard cover, 414 pages

Publisher InTech

Published online 11, April, 2012

Published in print edition April, 2012

Aquaculture has been expanding in a fast rate, and further development should rely on the assimilation of scientific knowledge of diverse areas such as molecular and cellular biology, and ecology. Understanding the relation between farmed species and their pathogens and parasites, and this relation to environment is a great challenge. Scientific community is involved in building a model for aquaculture that does not harm ecosystems and provides a reliable source of healthy seafood. This book features contributions from renowned international authors, presenting high quality scientific chapters addressing key issues for effective health management of cultured aquatic animals. Available for open internet access, this book is an effort to reach the broadest diffusion of knowledge useful for both academic and productive sector.

\title{
How to reference
}

In order to correctly reference this scholarly work, feel free to copy and paste the following:

Elisabeth Ytteborg, Jacob Torgersen, Grete Baeverfjord and Harald Takle (2012). The Atlantic Salmon (Salmo salar) Vertebra and Cellular Pathways to Vertebral Deformities, Health and Environment in Aquaculture, Dr. Edmir Carvalho (Ed.), ISBN: 978-953-51-0497-1, InTech, Available from:

http://www.intechopen.com/books/health-and-environment-in-aquaculture/the-atlantic-salmon-salmo-salarvertebra-and-cellular-pathways-to-vertebral-deformities

\section{INTECH}

open science | open minds

\author{
InTech Europe \\ University Campus STeP Ri \\ Slavka Krautzeka 83/A \\ 51000 Rijeka, Croatia \\ Phone: +385 (51) 770447 \\ Fax: +385 (51) 686166 \\ www.intechopen.com
}

\author{
InTech China \\ Unit 405, Office Block, Hotel Equatorial Shanghai \\ No.65, Yan An Road (West), Shanghai, 200040, China \\ 中国上海市延安西路65号上海国际贵都大饭店办公楼 405 单元 \\ Phone: +86-21-62489820 \\ Fax: +86-21-62489821
}


(C) 2012 The Author(s). Licensee IntechOpen. This is an open access article distributed under the terms of the Creative Commons Attribution 3.0 License, which permits unrestricted use, distribution, and reproduction in any medium, provided the original work is properly cited. 